\title{
O espaço para crianças produzido pelo Programa Minha Casa, Minha Vida: estudo de caso na região metropolitana de Belém, PA
}

\author{
Space for children produced by the "My House, My Life" \\ housing program: a case study in the metropolitan region \\ of Belém, Pará
}

\section{Shirley Coelho Müller José Júlio Ferreira Lima}

\section{Resumo \\ A} atual política de habitação de interesse social no Brasil determina que o lazer infantil seja atendido por espaços construídos especificamente para esse fim. Este artigo traz os resultados de pesquisa de espaços projetados para o lazer infantil em dois conjuntos habitacionais de interesse social produzidos pelo Programa Minha Casa, Minha Vida, Jardim Campo Grande e Jardim dos Pardais, ambos na Região Metropolitana de Belém, no Pará. Indaga-se que espaços de fato têm sido produzidos, partindo-se do princípio de que o corpo em movimento no espaço e as interações sociais possibilitadas pelo lazer são fundamentais para que o desenvolvimento sóciocognitivo e psicomotor das crianças aconteça de forma satisfatória. Investiga-se também a efetiva utilização desses espaços pelas crianças. O método de estudo de caso combina técnicas de análise do projeto arquitetônico e do espaço físico com a observação comportamental das crianças em seu lazer. Observou-se que os espaços de lazer infantil dos conjuntos estudados carecem de elementos que atendam de forma adequada à necessidade de lazer das crianças, que seu uso independe da quantidade de área destinada a esse fim, e que fatores como sensação de segurança ou insegurança e tipologia habitacional podem limitar ou estimular o uso desses espaços e a apropriação dos espaços comuns.

Palavras-chaves: Habitação de interesse social. Espaço de lazer infantil. Programa Minha Casa, Minha Vida.

\begin{abstract}
The current social housing policy in Brazil determines that children's recreation needs are met through the provision of spaces built specifically for that purpose. This paper presents the results of an assessment of children's recreation areas in two social housing projects produced by the My House, My Life Program (Programa Minha Casa Minha Vida-PMCMV), Jardim Campo Grande and Jardim dos Pardais, both in the metropolitan area of Belém, Pará. The study questions what kinds of spaces are actually being produced, based on the assumption that physical activity and the social interaction made possible through recreation areas are fundamental to ensure a satisfactory development of children's social-cognitive and psychomotor skills. This study also looks into the actual use of these spaces by children. The case study method combines architectural design and physical space analysis techniques with the behavioural observation of children in leisure activities. The study observed that, in the social housing projects analysed, the children's recreation spaces lack elements that adequately address the children's recreation needs, that their use does not depend on the amount of area destined for this purpose, and that factors such as a sense of security or insecurity and housing typology can limit or encourage the use of these spaces and the appropriation of public spaces.
\end{abstract}

Keywords: Social housing. Children’s play space. Minha Casa, Minha Vida Program. 


\section{Introdução}

A relação da criança com o espaço foi objeto de estudo de Piaget (2013), que constatou que a evolução da inteligência está relacionada ao espaço e acontece em paralelo com a evolução da afetividade e da vida relacional. $\mathrm{O}$ autor aponta que a gênese das estruturas da inteligência está no desenvolvimento sensório-motor, que antecede a linguagem e no qual se encontra a construção do espaço, que é elaborada desde os primeiros meses de vida do ser humano, pois é a partir do espaço que a criança estrutura suas primeiras noções de sentidos, como grande, pequeno, dentro e fora, usando seus próprios movimentos.

Traçando um paralelo com os estudos de Piaget, Ferreira Neto (1995) salienta que o período do desenvolvimento pré-operatório é a fase em que se desenvolvem os "skills" ou habilidades motoras básicas (correr, saltar, atirar, pontapear, apanhar, trepar, etc.), diretamente ligadas ao desenvolvimento da noção de organização/relação dos objetos, do espaço, do tempo e de causalidade, portanto fundamentais para o desenvolvimento da inteligência. $\mathrm{O}$ autor reforça que a privação de espaço traz graves consequências para o desenvolvimento da criança, em forma de atrasos sensório-motores, cognitivos e psicoafetivos, chamando a atenção para as condições desfavoráveis a que as crianças têm sido submetidas pelo pouco espaço físico ofertado e pelas condições da vida social (FERREIRA NETO, 1995).

No passado essa necessidade de espaço era atendida naturalmente, entretanto a sociedade ocidental passou por uma série de transformações, iniciadas com o advento da Revolução Industrial e aprofundadas no período após a Segunda Grande Guerra, que alteraram o crescimento demográfico, passando pelos modos de produção e comunicação, o que gerou impactos nas cidades e na rotina de seus habitantes, inclusive das crianças. A vida passou a se organizar em função do trabalho, o tempo passou a ser regido pelo relógio, e o tempo do trabalho, para homens, mulheres e crianças, foi dilatado a ponto de gerar uma reação da classe trabalhadora, surgindo, assim, a questão do lazer como um direito (SANTINI, 1993). No entanto, quanto ao lazer infantil ainda não há consenso. Questiona-se se a brincadeira pode ser considerada lazer, se a brincadeira pode ser utilizada como meio de aprendizagem e até mesmo se a escola pode ser tida como trabalho infantil (MARCELLINO, 2002).

Quanto ao impacto causado nas cidades, desde as idealizações dos utopistas, a importância de garantir aos citadinos a experiência do lazer foi reconhecida, culminando com a proposição da arquitetura moderna, que considera o lazer como uma das funções da cidade, devendo ser distribuídos nesta, em uma proporção justa, espaços onde o lazer possa ser desfrutado (LE CORBUSIER, 1993; CHOAY, 2005). Camargo (1984) questiona onde a população das cidades pode vivenciar sua necessidade de lazer e se é possível falar de lazer em se tratando de populações pobres, propondo que

\section{[...] toda política urbana de lazer deve iniciar-se por uma política habitacional justa, que respeite as necessidades de um espaço social íntimo e externo nas residências [...]. (CAMARGO, 1984, p. 160).}

Entretanto, a realidade brasileira está longe de obedecer à proporcionalidade sugerida pelos arquitetos modernos, e a política habitacional atual do Brasil, da qual o Programa Minha Casa, Minha Vida (PMCMV) faz parte, tem produzido conjuntos em locais afastados da malha urbana que carecem de equipamentos públicos.

Considerando a necessidade de espaço para o desenvolvimento sociocognitivo e psicomotor das crianças, considerando também que a moradia digna é um dos princípios no qual se baseia a Política Nacional de Habitação e que o direito à moradia e ao lazer são direitos sociais reconhecidos pela Constituição Federal do Brasil, esta pesquisa teve por objeto de estudo o espaço projetado para a brincadeira das crianças, entendida como lazer infantil, em empreendimentos construídos sob a égide do PMCMV para a faixa de 0 a 3 salários mínimos.

\section{Habitação social e lazer no Brasil}

A crise da habitação popular no Brasil remonta ao final do século XIX, porém a intervenção estatal data dos anos 1930, quando o Governo Vargas enfrentou a questão habitacional como um problema social e, a partir de então, foram criados órgãos ou departamentos com a função específica de atuar na produção de habitação popular (BRUNA, 2010; BONDUKI, 2011). Bonduki (2011) aponta que as propostas mais inovadoras de habitação social no Brasil foram os conjuntos habitacionais de inspiração moderna, edificados nos anos 1940, destacando-se a produção habitacional dos Institutos de Aposentadoria e Pensão (IAPs), Fundação Casa Popular (FCP) e Departamento de Habitação Popular do Rio de Janeiro (DHP).

Segundo Bruna (2010, p. 167), “[...] havia no Brasil, desde a década de 1930, a consciência e cultura para a efetiva implantação dos princípios teóricos do movimento moderno [...]”. Apesar de se guiarem 
por normas particulares, é visível a influência da arquitetura moderna nos conjuntos habitacionais dessas instituições, pela busca de reduzir os custos da construção (por meio da racionalização, industrialização, verticalização e padronização), nas novas tipologias de projeto, na eliminação da noção de lote e terreno privado, e na inclusão de equipamentos coletivos, como ginásios, playgrounds e clubes, que atenderiam, entre outras, à necessidade de jogo e lazer de crianças, adolescentes e adultos (BRUNA, 2010; BONDUKI, 2011).

A preocupação com o atendimento dessa necessidade levou o engenheiro-arquiteto Rubens Porto, assessor técnico do Ministério do Trabalho, ao qual estavam vinculados os IAPs, a recomendar a tipologia de blocos de apartamentos sobre pilotis no livro em que estabelecia diretrizes e normas de projeto para conjuntos de habitação social, destacando que o espaço resultante do uso destes deveria ser aproveitado para o lazer das crianças e adultos (BRUNA, 2010; BONDUKI, 2011). Mesmo adotando diferentes tipologias, os conjuntos habitacionais edificados pelos IAPs, de modo geral, foram beneficiados por áreas livres e equipamentos específicos para o lazer. Como exemplo, temos o Conjunto Residencial do Realengo, projeto de Carlos Frederico Ferreira, edificado pelo Instituto de Aposentadorias e Pensões dos Industriários (Iapi) no subúrbio do Rio de Janeiro e concluído em 1943, que contava com praças e quadras de esporte (BOTAS, 2010; BONDUKI, 2011).

Outros exemplos de conjuntos desenvolvidos pelo Iapi equipados para o lazer são o Conjunto Residencial da Lagoinha, em Belo Horizonte, projetado por White Lírio da Silva, José Barreto de Andrade e Antônio Neves, inaugurado em 1948, que dispõe de pátios centrais no interior dos blocos em forma de "U" e tetos-jardim interligados, além de praças, quadras esportivas e playground, e o Conjunto Residencial da Mooca, em São Paulo, de autoria de Paulo Antunes Ribeiro, concluído em 1950, dotado de área livre para lazer com playground, implantada na área central (CASTRIOTA; ARAÚJO, 2009; BRUNA, 2010; BONDUKI, 2011). Nos conjuntos habitacionais dos IAPs evidencia-se a valorização das áreas verdes, propícias ao lazer, inspirados nas cidades-jardim inglesas, como o Conjunto Residencial São Brás, em Belém, projetado pelo arquiteto Edmar Penna de Carvalho, construído entre 1949 e 1951, originalmente cercado por vegetação (BONDUKI, 2011; PANTOJA, 2014).

O Conjunto Residencial Prefeito Mendes de Moraes, ou Pedregulho, projetado por Affonso Eduardo Reidy para o DHP e inaugurado em 1947 no Rio de Janeiro, sobressai-se do ponto de vista arquitetônico, estético e social, conjugando habitação propriamente dita com jardins, equipamentos sociais e de lazer, como teatro infantil, escola com ginásio e piscina, campos de esporte e playground (BRUNA, 2010; MINDLIN, 2000). Sob a influência da arquitetura moderna e do Pedregulho, a FCP construiu o Conjunto Residencial Presidente Getúlio Vargas, em 1953, também no Rio de Janeiro, dispondo de áreas livres, parques esportivos e um bosque preservado (BONDUKI, 2011; DINIZ, 2007). A proposta elaborada para a FCP de centralizar a política habitacional foi realizada sob o regime militar em 1964, quando se criou o Banco Nacional de Habitação (BNH), sendo extintas a FCP e as unidades habitacionais dos IAPs negociadas com os moradores, individualizando a propriedade e desestruturando a proposta de habitação como serviço público, o que culminou na gradual destruição dos espaços públicos e equipamentos comunitários, inclusive áreas de recreação (MELO, 1990; BONDUKI, 2011).

Segundo Bonduki (2011, p. 135), desde o período final dos IAPs já era possível se perceber "o empobrecimento gradativo dos projetos habitacionais", que chegou ao auge na produção habitacional do $\mathrm{BNH}$, denominada por Benetti (2012) como crise da simplificação modernista. A busca pela redução dos custos do $\mathrm{BNH}$ levou à construção de conjuntos habitacionais em grandes lotes periféricos, favorecendo o isolamento dos moradores, relegados a lugares carentes de equipamentos sociais e de lazer (BENETTI, 2012). Como exemplo tem-se o Conjunto Habitacional Gleba I, ou Nova Marambaia, em Belém, construído em área de expansão, ainda não efetivamente povoada à época, cujo projeto previa algumas pracinhas, as quais deveriam ter sido equipadas pela Prefeitura, porém não foram concluídas (TRINDADE JUNIOR, 1993). Bruna (2010) e Bonduki (2011) acreditam que houve um verdadeiro retrocesso em relação à produção da Era Vargas no que diz respeito à qualidade arquitetônica, à implantação urbanística e ao modo de morar.

A estratégia empresarial do $\mathrm{BNH}$, cujos recursos foram aplicados majoritariamente no mercado médio, aliada à desvalorização do salário mínimo e à crise econômica, articulada com a luta pela democracia contra o regime autoritário, gerou insatisfação com a política habitacional e o acirramento das críticas (BONDUKI, 2008). Sucedendo o período do regime militar, o governo Sarney extingue o BNH, cujas atribuições, corpo técnico e acervo foram parcialmente assimilados pela Caixa Econômica Federal (Caixa) (AZEVEDO, 1988; BONDUKI, 2008). Depois da 
extinção do BNH, em 1986, a produção estatal de moradia decresceu abruptamente, e no período pós$\mathrm{BNH}$ os municípios, estados e a União buscaram recursos para financiar programas habitacionais alternativos, como urbanização de favelas e assentamentos precários, entre eles o programa Favela-Bairro, no Rio de Janeiro, que buscava a integração da favela na cidade, por meio de várias medidas e obras de infraestrutura e equipamentos coletivos, entre as quais a criação de espaços de encontro e lazer (AZEVEDO, 2007; BONDUKI, 2008; MENDES, 2006; BENETTI, 2012).

Nesse período destaca-se também a atuação dos movimentos sociais urbanos, articulados no Movimento Nacional de Reforma Urbana, criado em janeiro de 1985, que trabalhou ativamente pela emenda popular da reforma urbana durante a Assembleia Nacional Constituinte em 1987 e, mais tarde, pela regulamentação do capítulo constitucional sobre política urbana, que culminou com a promulgação do Estatuto da Cidade, em 2001 (FERNANDES, 2010; SAULE JÚNIOR; UZZO, 2013). A Política Nacional de Habitação, no entanto, só foi retomada pelo governo Lula, que em 2009 lança o Programa Minha Casa, Minha Vida (PMCMV), criado no âmbito do Ministério do Planejamento e gerido pela Caixa, com o objetivo de fazer frente à crise econômica mundial, impulsionando a indústria da construção civil, além de atender à demanda por habitação, incentivando a produção e a aquisição de unidades habitacionais, com subsídio total para habitação de interesse social, atendendo famílias com renda mensal de zero a três salários mínimos (BENETTI, 2012; CARDOSO; ARAGÃO, 2013).

Apesar da meta ambiciosa de construir mais de três milhões de unidades nas duas fases do Programa e da possibilidade de atendimento da população de baixa renda, o PMCMV apresenta aspectos controversos, como a falta de articulação com a política urbana e o Plano Nacional de Habitação, produzindo conjuntos habitacionais extensos, de morfologia monótona, em locais distantes e carentes de emprego e equipamentos públicos, similar ao que foi realizado pelo BNH (CARDOSO, 2011; BENETTI, 2012; CARDOSO; ARAGÃO, 2013). A provisão de equipamentos de lazer faz parte das diretrizes para a elaboração dos projetos de empreendimentos de habitação de interesse social do PMCMV, especificadas na Portaria n. 168/2013 do Ministério das Cidades, que institui a obrigatoriedade de espaço descoberto para lazer e recreação infantil e quadra de esportes (BRASIL, 2013). No entanto, exceções são admitidas, e o único critério de análise dos equipamentos é o econômico.
Desse modo, a política habitacional no Brasil tem oscilado através do tempo, de acordo com ideologias e/ou influências econômicas, e pouco tem sido contemplada a questão habitacional em sua complexidade, preponderando os aspectos quantitativos em detrimento dos aspectos sociais e qualitativos, a exemplo da política atual. Tratando especificamente de habitação de interesse social, Reis e Lay (2010, p. 117) frisam que se deve ir além dos aspectos quantitativos, buscando-se a sustentabilidade social da habitação, que será alcançada se for “"[...] pensada como habitação qualificada, isto é, que satisfaça as necessidades de seus moradores e qualifique suas vidas, através de projetos arquitetônicos adequados [...]", especialmente no que diz respeito às relações entre as edificações e os espaços abertos.

Assim, considerando a necessidade de buscar a humanização do habitar, em que as necessidades dos habitantes, além do abrigar-se, sejam de fato levadas em conta, essa pesquisa avaliou a qualidade do espaço que tem sido ofertado às crianças nos conjuntos habitacionais de interesse social construídos sob a égide do PMCMV, possibilitando ou não o lazer tão necessário ao desenvolvimento delas.

\section{Projeto de espaços de lazer e as necessidades de desenvolvimento infantil}

A importância de projetar adequadamente espaços que estimulem o desenvolvimento infantil é condicionada pelo papel fundamental do brincar para o desenvolvimento psicomotor da criança (LIMA, 1989). O resgate do espaço, do tempo e da naturalidade da brincadeira é relacionado com o modo que a solicitação motora e muscular das brincadeiras infantis contribui para a maturação das condutas. Segundo Velasco (1996), esse desenvolvimento se estrutura em condutas:

(a) motoras de base: equilíbrio, coordenação dinâmica geral, respiração consciente e coordenação motora fina;

(b) neuromotoras: esquema corporal, controle psicomotor e lateralidade; e

(c) perceptivo-motoras: orientação corporal, espacial e temporal.

Tratando da relação entre corpo e espaço, Ferreira Neto (1995) considera como premissa que o espaço construído para crianças deva atender a suas necessidades corporais, quais sejam: movimento, espaço, afetividade, contato com a natureza, materiais diversificados, exploração do meio, acesso ao jogo, ser livre, experimentar e transformar 
o meio material e institucional, e convivência em grupo. Para propiciar o desenvolvimento e a conquista de habilidades motoras, imaginativas, artísticas e contato com a natureza, o autor propõe um modelo subdividido em quatro zonas distintas: espaço livre, aparelhos fixos, "selvagem" e ateliês. A zona "selvagem", arborizada e equipada com cabanas, areia, terra, zona acidentada, riachos, valas, pequenos montes de terra, madeiras, ferramentas, caixas, pneus, etc., assemelha-se ao indicado por Alexander (2013) em sua proposta de parque rústico e dinâmico.

A necessidade de recreação livre, que permite à criança explorar, experimentar e exercer a criatividade, demanda espaço propício e estimulante, segundo Oliveira (2004), que reforça que o desenvolvimento dessas potencialidades influi no aprendizado da ciência, necessidade também destacada por Ferreira Neto (1995), Jacobs (2003) e Borges (2008). Considerando os benefícios da atividade ao ar livre para a saúde física, mental e psicológica das crianças, McCurdy, Winterbottom e Mehta (2010) apontam que a proximidade de ambientes naturais e a presença de elementos, como playgrounds, cul-de-sacs e calçadas no ambiente construído, encorajam essa atividade, referindo-se a pesquisas realizadas nos EUA e no Canadá que evidenciam a necessidade de prescrever uma rotina diária de recreação livre como cuidado pediátrico, a fim de evitar ou tratar a obesidade infantil e doenças relacionadas, além de melhorar a atenção e reduzir o estresse nas crianças.

Tendo em vista a necessidade de estimular a fantasia, a imaginação e a livre expressão de todo o seu vocabulário físico-corporal (correr, agachar, esconder, escorregar, subir, pular, equilibrar, escalar, pendurar, descer, olhar, puxar, empurrar, tocar, virar, subir, encostar), Pina (1996) traça recomendações gerais de projeto de parque lúdico para a representação paulista do Serviço Social do Comércio (Sesc). O autor acredita que, para proporcionar às crianças sensações, emoções e possibilidade de interatividade, deve-se substituir o modelo tradicional de playground, que apresenta poucas novidades em termos de desenho e pouca preocupação educativa, por instalações lúdicas que reúnam novas concepções de equipamentos e design, valendo-se de materiais variados, integrados a um ambiente agradável e atrativo. Lima (1989, p. 72) também faz críticas aos playgrounds tradicionais e ressalta que o espaço para crianças deve ser elaborado o suficiente "[...] para estimular a curiosidade e a imaginação da criança, mas incompleto o bastante para que ela se aproprie e transforme esse espaço através de sua própria ação [...]".
Atendendo à necessidade de socialização e de contato com a diversidade, Dieckert e Monteiro (1983), Ferreira Neto (1995), Oliveira (2004), Alexander (2013) e Borges (2014) julgam ser indispensável proporcionar à criança a convivência em grupo. Os mesmos autores sugerem a necessidade do contato com a natureza, vital para a absorção de nutrientes, para oportunizar uma variedade de estímulos, o desenvolvimento da capacidade de observação e a percepção do espaço. Segundo Oliveira (2004), crianças que se relacionam com a natureza desenvolvem comportamento mais harmonioso, brincam melhor e são mais criativas. Para aguçar os sentidos, Jacobs (2003), Oliveira (2004) e Alexander (2013) apontam que é preciso assegurar que as crianças tenham acesso a uma diversidade de atividades e zonas de sol e sombra, que possibilitem o uso do espaço em diferentes horários e estações do ano.

Pensando na necessidade de garantir a segurança, Dieckert e Monteiro (1983) propõem um parque dividido em zonas interligadas, que atenda ao lazer e à prática esportiva de adultos e crianças de todos os sexos e faixas etárias. Quanto à localização, é indicado que a distância entre o espaço de lazer e a habitação seja reduzida, para que a vigilância natural possa ser exercida pelos adultos (FERREIRA NETO, 1995; JACOBS, 2003; BORGES, 2008). Dieckert e Monteiro (1983) recomendam que essa distância não deve exceder os $200 \mathrm{~m}$.

A centralidade e o fácil acesso são elementos importantes a serem considerados ao se projetarem parques infantis, situando-os em locais convenientes e reconhecidos por todos como o centro, de acordo com Jacobs (2003), que sirvam de pontos de orientação e estejam ligados às áreas residenciais, segundo Neufert (2013), enquanto Borges (2008) propõe que a escolha do local seja feita por meio de participação popular e conte com uma vizinhança diversificada.

Neufert (2013) cita critérios estabelecidos pelas normas alemãs ditadas pelo Deutsches Institut für Normung (DIN), entre as quais a norma DIN 7926 (BERLIN, 1983), que estabelece a obrigatoriedade de áreas recreativas para crianças de até 6 anos, crianças de 6 a 12 anos e adultos em conjuntos habitacionais a partir de três unidades de moradia, e a norma DIN 18034 (BERLIN, 2012), que determina um mínimo de $5 \mathrm{~m}^{2}$ de área recreativa por unidade de moradia, e de $40 \mathrm{~m}^{2}$ o tamanho mínimo recomendado para playgrounds. A normativa da Associação Brasileira de Normas Técnicas (ABNT) para playgrounds, a NBR 14350 (ABNT, 1999), se restringe à segurança dos brinquedos e a estabelecer diretrizes para a elaboração de contrato de aquisição/fornecimento de equipamentos. 


\section{Método da pesquisa}

A adoção de critérios estabelecidos compõe a metodologia de estudo de caso, especificada em um protocolo conforme proposto por Yin (2001), combinando técnicas de análise do projeto arquitetônico no que se refere ao espaço físico, ou seja, a arquitetura dos espaços de lazer, por meio da observação de vestígios físicos e comportamentais dos usuários.

$\mathrm{Na}$ análise do projeto arquitetônico verificou-se a previsão de área equipada para o lazer e/ou áreas livres efetivamente utilizáveis pelas crianças, além de questões relativas à localização e à dimensão dessas áreas. Na análise do espaço físico comparouse o espaço construído com o espaço projetado. A observação de vestígios físicos (ZEISEL, 1993), cujas categorias estão demonstradas no Quadro 1, foi efetuada para inferir o uso do ambiente pelas pessoas através dos reflexos de atividades realizadas.
Para analisar a arquitetura dos espaços de lazer foi construído um roteiro de observação (Quadro 2) contendo os elementos sugeridos pelos autores para o atendimento das necessidades de desenvolvimento infantil, reunidos em quatro aspectos: localização, configuração, equipamentos e ambientais.

Através da observação comportamental foi possível examinar se e como as crianças usavam o ambiente projetado para seu lazer, assim como outros ambientes apropriados para esse fim (ZEISEL, 1993). As observações foram registradas em mapas comportamentais apresentados a seguir. Essa combinação de técnicas e critérios foi feita para investigar os espaços produzidos para o lazer infantil nos conjuntos habitacionais de interesse social produzidos pelo PMCMV na RMB, tendo em vista que a atividade física e as interações sociais proporcionadas pela brincadeira são fundamentais para o desenvolvimento infantil.

\section{Quadro 1 - Vestígios físicos}

\begin{tabular}{|c|c|}
\hline CATEGORIAS & TIPOS \\
\hline $\begin{array}{l}\text { Subprodutos } \\
\text { do uso }\end{array}$ & $\begin{array}{l}\text { Desgastes do ambiente pelo uso: uso pode desgastar partes do ambiente. Ex.: grama pisoteada por } \\
\text { pessoas ao buscar caminho mais curto. } \\
\text { Rastros: objetos físicos que ficam para trás como o resultado de algumas atividades realizadas. Ex.: } \\
\text { cadeiras vazias na calçada. } \\
\text { Vestígios ausentes: ao contrário dos anteriores indica ausência de atividade. Ex.: sacada sem } \\
\text { cadeiras. }\end{array}$ \\
\hline Adaptações de uso & $\begin{array}{l}\text { Propriedades: quando os usuários adicionam ou removem coisas de um cenário e criam novas } \\
\text { oportunidades de atividade. Ex.: brinquedo adicionado a um lote vazio pode transformá-lo em um } \\
\text { playground. } \\
\text { Separações: mudanças que separem ambientes antes integrados, incrementando qualidades como } \\
\text { controle, privacidade etc. Pode separar fisica, visual, auditiva, olfativa ou simbolicamente. Ex.: } \\
\text { colocar obstáculos para impedir estacionamento de carros na frente da residência. } \\
\text { Conexões: adaptações de uso que conectem dois lugares permitindo que as pessoas interajam de um } \\
\text { novo modo. Ex.: rasgos nas cercas das quadras de esporte. }\end{array}$ \\
\hline $\begin{array}{c}\text { Manifestações } \\
\text { do eu }\end{array}$ & $\begin{array}{l}\text { Personalização: pessoas usam o ambiente para expressar sua individualidade. Ex.: transformar } \\
\text { janelas, portas, paredes em vitrines, cenários. } \\
\text { Identificação: pessoas usam o ambiente para possibilitar que outros os identifiquem mais } \\
\text { facilmente. Ex.: nome de família na porta. } \\
\text { Participação em grupo: pessoas usam o ambiente para exibir o grupo de que fazem parte. Ex.: } \\
\text { estátuas religiosas, diplomas nas paredes, adesivos em carros. }\end{array}$ \\
\hline $\begin{array}{l}\text { Mensagens } \\
\text { públicas }\end{array}$ & $\begin{array}{l}\text { Oficiais: dentro da legalidade, sempre tem um objetivo. Ex.: placas com nomes de } \\
\text { estabelecimentos, nomes de ruas. } \\
\text { Não oficiais: pessoas ou grupos usam o ambiente para comunicar sua publicidade por meios não } \\
\text { adequados especificamente para esse fim. Ex.: anúncio em papelão, cartazes colados nos postes. } \\
\underline{\text { Ilegítimas: mensagens não planejadas para o público em geral, cujas modificações no ambiente são }} \\
\text { ilegais. Ex.: pichação nas paredes. }\end{array}$ \\
\hline
\end{tabular}

Fonte: adaptado de Zeisel (1993). 
Quadro 2 - Roteiro de observação dos espaços de lazer

\begin{tabular}{|c|c|c|}
\hline Aspectos & Elementos & Autores \\
\hline \multirow{4}{*}{ Localização } & $\begin{array}{l}\text { Proximidade } \\
\text { (Fica próximo das residências?) }\end{array}$ & $\begin{array}{l}\text { Dieckert; Monteiro (1983); Ferreira Neto (1995); } \\
\text { Jacobs (2003); Borges (2008); Alexander (2013) }\end{array}$ \\
\hline & $\begin{array}{l}\text { Vigilância natural } \\
\text { (Existem aberturas, circulação de pessoas?) }\end{array}$ & $\begin{array}{l}\text { Dieckert; Monteiro (1983); Ferreira Neto (1995); } \\
\text { Jacobs (2003); Borges (2008) }\end{array}$ \\
\hline & $\begin{array}{l}\text { Centralidade } \\
\text { (É localizada em uma região central do residencial?) }\end{array}$ & \multirow{2}{*}{ Jacobs (2003); Borges (2008); Neufert (2013) } \\
\hline & $\begin{array}{l}\text { Facilidade de acesso } \\
\text { (É de fácil acesso?) }\end{array}$ & \\
\hline \multirow{4}{*}{ Configuração } & $\begin{array}{l}\text { Complexidade visual } \\
\text { (Possui complexidade visual?) }\end{array}$ & $\begin{array}{l}\text { Dieckert; Monteiro (1983); Lima (1989); } \\
\text { Ferreira Neto (1995); Pina (1996); Jacobs (2003); } \\
\text { Oliveira (2004); Borges (2008) }\end{array}$ \\
\hline & $\begin{array}{l}\text { Materiais, texturas variados } \\
\text { (Tem materiais e texturas variados?) }\end{array}$ & $\begin{array}{l}\text { Dieckert; Monteiro (1983); Ferreira Neto (1995); } \\
\text { Pina (1996); Oliveira (2004); Alexander (2013) }\end{array}$ \\
\hline & $\begin{array}{l}\text { Espaço para correr e brincar e para recreação livre } \\
\text { (Possui espaço para recreação livre/correr?) }\end{array}$ & $\begin{array}{l}\text { Ferreira Neto (1995); Pina (1996); Jacobs (2003); } \\
\text { Oliveira (2004); Borges (2008); Alexander (2013) }\end{array}$ \\
\hline & $\begin{array}{l}\text { Acesso ao jogo } \\
\text { (Existe campo para jogos?) }\end{array}$ & $\begin{array}{l}\text { Dieckert; Monteiro (1983); } \\
\text { Ferreira Neto (1995); Borges (2014) }\end{array}$ \\
\hline \multirow{3}{*}{ Equipamentos } & $\begin{array}{l}\text { Elementos móveis ou interativos } \\
\text { (Possui elementos móveis, interativos?) }\end{array}$ & $\begin{array}{l}\text { Lima (1989); Ferreira Neto (1995); Pina (1996); } \\
\text { Alexander (2013) }\end{array}$ \\
\hline & $\begin{array}{l}\text { Aparelhos de formas, tamanhos e usos diversos } \\
\text { (Existem brinquedos variados?) }\end{array}$ & Dieckert; Monteiro (1983); Ferreira Neto (1995) \\
\hline & $\begin{array}{l}\text { Segurança do brinquedo } \\
\text { (Os brinquedos são seguros?) }\end{array}$ & NBR 14350-1 (ABNT, 1999) \\
\hline \multirow{3}{*}{ Ambientais } & $\begin{array}{l}\text { Zonas de sol e sombra } \\
\text { (Existem zonas de sol e sombra?) }\end{array}$ & Jacobs (2003); Oliveira (2004); Borges (2008) \\
\hline & $\begin{array}{l}\text { Iluminação artificial } \\
\text { (Existe iluminação artificial?) }\end{array}$ & Dieckert; Monteiro (1983) \\
\hline & $\begin{array}{l}\text { Contato com vegetação } \\
\text { (Possibilita contato com vegetação?) }\end{array}$ & $\begin{array}{l}\text { Dieckert; Monteiro (1983); Ferreira Neto (1995); } \\
\text { Oliveira (2004); Borges (2008); Alexander (2013) }\end{array}$ \\
\hline
\end{tabular}

\section{Estudo de caso: os espaços de lazer infantil nos Residenciais Jardim Campo Grande e Jardim dos Pardais}

Foi realizado estudo de caso nos espaços de lazer infantil em dois conjuntos habitacionais de interesse social produzidos pelo PMCMV, os Residenciais Jardim Campo Grande e Jardim dos Pardais, situados nos municípios paraenses de Ananindeua e Marituba respectivamente. Esses municípios fazem parte da Região Metropolitana de Belém (RMB) e formam com ela uma mancha contínua, interligada pela rodovia BR-316, que atravessa quase todos os demais municípios metropolitanos (UNIVERSIDADE...; CONSELHO..., 2015). A expansão dessas cidades aconteceu de forma semelhante, e em ambas a natureza da ocupação é heterogênea, e a aglomeração e a provisão de equipamentos urbanos consolidaram-se ao longo da rodovia. A porção ao norte da BR-316 foi incorporada à área urbana pela construção de conjuntos habitacionais em área rural, e o hiato entre a rodovia e essas terras foi reservado à especulação imobiliária e passou por processo de ocupação informal, impulsionado a partir de 1982 (LIMA; CARDODO; HOLANDA, 2005). Na porção ao sul da BR-316 tem-se repetido o acima descrito com relação ao norte, e é onde vem sendo construída a maior parte dos empreendimentos do PMCMV (UFPA; CNPq, 2015).

Os municípios de Ananindeua e Marituba eram predominantemente rurais até 1991, quando a população urbana de Ananindeua passou a ser de $84 \%$, atingindo $99 \%$ no ano 2000 , enquanto Marituba quase duplicou sua população no mesmo período (LIMA; CARDOSO; HOLANDA, 2005). Os dados do Censo 2010 apontam que a parcela de habitantes na faixa etária da infância (0 a 12 anos) no município de Ananindeua corresponde a $22 \%$ da população, enquanto em Marituba essa proporção é de $25 \%$ da população do município (IBGE, 2010). Além disso, segundo resultados do Censo 2010, as taxas de fecundidade evidenciam que o número de filhos é inversamente proporcional à renda familiar 
no Brasil, e a região Norte detém as mais altas taxas de fecundidade para todas as faixas de renda, em especial nas classes com rendimentos inferiores (IBGE, 2010). Portanto, infere-se que uma parcela significativa dos moradores de conjuntos habitacionais de interesse social produzidos pelo PMCMV encontra-se no período da infância, faixa etária que interessa a esta pesquisa (IBGE 2010).

Esses dados, aliados à natureza da inserção urbana dos empreendimentos do Programa Minha Casa, Minha Vida para a faixa de renda de zero a três salários mínimos, de modo geral em zonas periféricas, distante da malha urbana consolidada e dos equipamentos coletivos (inclusive os de lazer), reforçam a necessidade de prover ambientes adequados ao desenvolvimento infantil, com a implantação de áreas de lazer próximas às habitações.

\section{Análise dos projetos e dos espaços de lazer}

A política habitacional efetivada pelo PMCMV, associada à restrição de custos e à necessidade de obter lucros por parte da iniciativa privada, leva à redução de área das unidades habitacionais e à repetição de modelos estabelecidos, buscando construir o maior número de unidades em um empreendimento, especialmente em se tratando de habitação de interesse social, como os que foram analisados nesta pesquisa, representantes de tipologias distintas.

O Residencial Jardim Campo Grande, localizado no município de Ananindeua, obedece à tipologia condomínio fechado vertical, em que o conjunto de prédios é implantado em uma área comum, segregada da malha urbana (Figura 1).

Seu projeto urbanístico nitidamente procura ter o melhor aproveitamento do terreno, de formato irregular. $\mathrm{O}$ desenho viário interno segue a conformação da gleba e é composto de quatro vias internas, sendo a maior delas a que se relaciona com o sistema viário da cidade; as demais se conectam a esta. A gleba foi parcelada em cinco quadras, quatro delas com área média de 2.249,50 $\mathrm{m}^{2}$, em formato de paralelogramo, com quatro blocos implantados, e uma quadra maior, de $3.555,80 \mathrm{~m}^{2}$, em formato de "L", com cinco blocos implantados (Figura 2).

\section{Figura 1 - Localização e caracterização do Residencial Jardim Campo Grande}

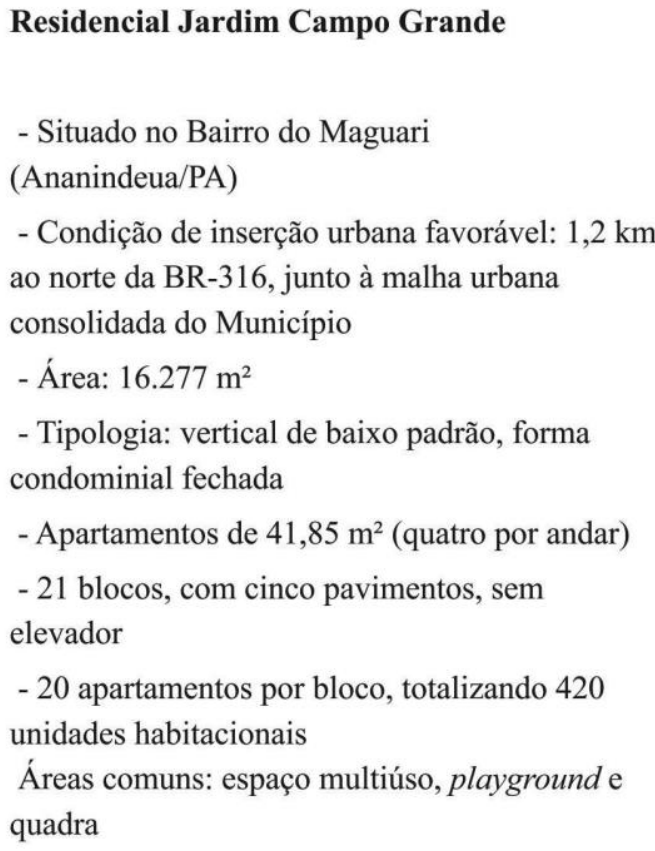

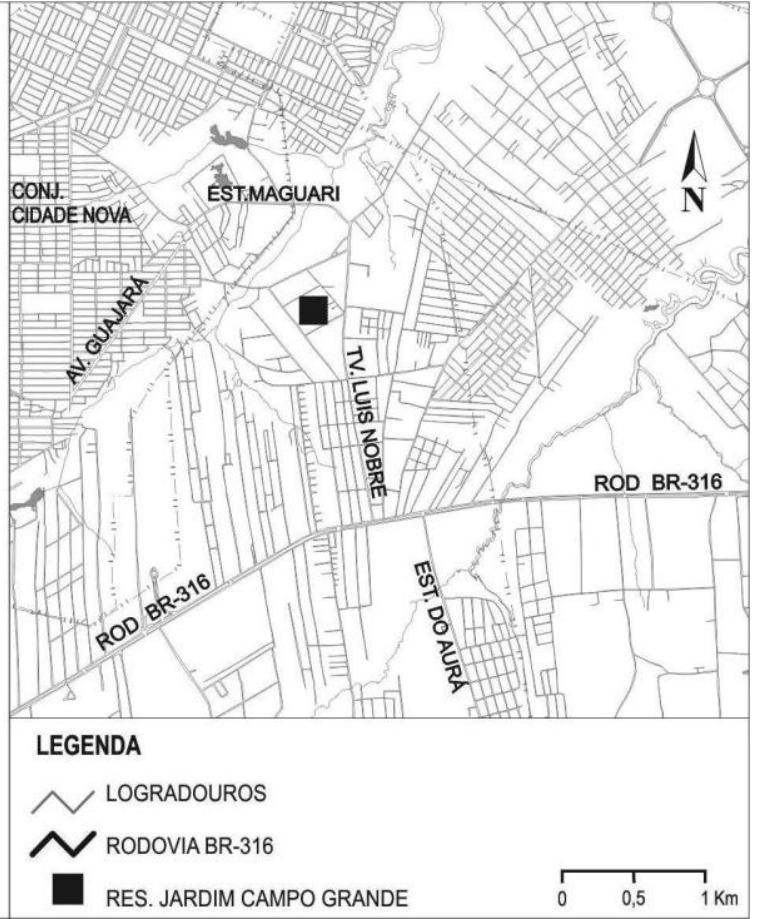

Fonte: adaptado de Construtora Acrópole (2014) e Ananindeua (2014). 
Figura 2 - Diagrama do sistema viário e localização das áreas residenciais, equipamentos de lazer infantil e comunitários do Residencial Jardim Campo Grande

LEGENDA:

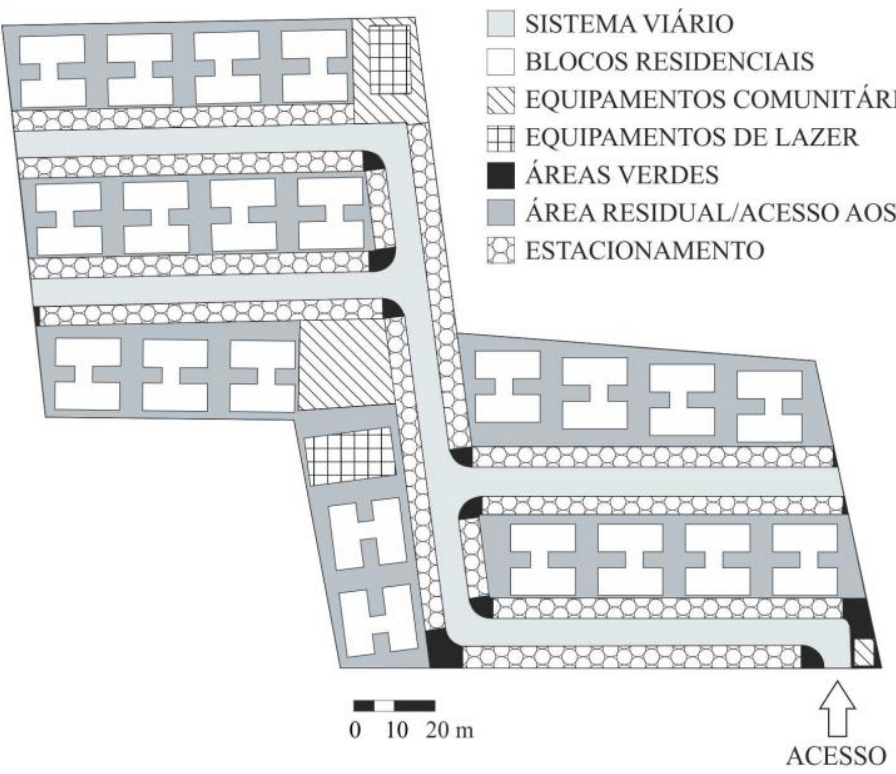

Fonte: adaptado de Construtora Acrópole (2014).

O Residencial Jardim dos Pardais segue a tipologia de habitação unifamiliar isolada no lote, de ocupação extensiva, abrangendo uma área 6,44\% maior que o Jardim Campo Grande (Figura 3).

O condomínio é horizontal, aberto e integrado à malha viária existente através da Rua WE-01, que o conecta as passagens Santa Teresa D’Ávila e Vera Cruz, já existentes, contando também com quatorze vias internas perpendiculares à Rua WE-01 e conectadas a esta, além da Rua WE-02, que separa as quadras centrais e seis vias de contorno. As quadras são regulares, de formato retangular, sendo doze delas para uso habitacional, com áreas de $5.440 \mathrm{~m}^{2}$ (34 lotes) e $5.760 \mathrm{~m}^{2}$ (36 lotes), e duas quadras para equipamento comunitário, de comércio e de lazer (Figura 4).

Durante a observação do espaço físico do Residencial Jardim dos Pardais percebeu-se que o tráfego de pedestres é dificultado por restos de material de construção e que o mato nas calçadas avança sobre o limite frontal ou lateral demarcado por piquetes, "estrangulando" a passagem junto aos postes e induzindo o uso da via para isso. Os quintais e jardins têm cerca de $5 \mathrm{~m}$ de comprimento, e vários são tomados por varais para a secagem de roupas, restringindo áreas que poderiam servir ao lazer infantil.

A análise dos vestígios físicos no que diz respeito ao lazer revelou ocorrências nas categorias
"Subprodutos do uso" e "Adaptações do uso". $\mathrm{Na}$ categoria "Subprodutos do uso" no Jardim dos Pardais verificaram-se indícios de "Desgastes do ambiente pelo uso" no playground e de "Vestígios ausentes" no "campinho de futebol" (Campo de Pelada), projetado, mas não utilizado. Na mesma categoria, no Jardim Campo Grande a única ocorrência registrada foi de "Desgastes do ambiente pelo uso" no gramado junto à quadra de areia.

$\mathrm{Na}$ categoria "Adaptações do uso" foram assinalados vestígios do tipo "Propriedades" nos dois residenciais, uma casinha de brinquedo no Jardim Campo Grande e um banco no Jardim dos Pardais, e "Separações", caracterizada por alterações que separam ambientes originalmente integrados, fazendo com que desenvolvam novas qualidades, como encontrado no Jardim Campo Grande, onde um arranjo de vegetação criou barreira visual, tornando a área de acesso em área de lazer. As observações estão registradas nas Figuras 5 e 6, abaixo.

A análise do projeto do Jardim dos Pardais indica que $63 \%$ da área do conjunto é destinada aos lotes residenciais, o que se justifica pela tipologia de condomínio horizontal, cabendo ao sistema viário $25 \%$ da área, enquanto as áreas verdes e de lazer ocupam juntas apenas $6 \%$ da área total do conjunto, como se pode verificar na Figura 7, a seguir. 
Figura 3 - Localização e caracterização do Residencial Jardim dos Pardais

\section{Residencial Jardim dos Pardais}

- Situado no Bairro do Decouville (Marituba/PA)

- Condição de inserção urbana desfavorável: a menos de $1 \mathrm{~km}$ ao sul da BR-316, distante da malha urbana consolidada do Município

- Área: $105.000 \mathrm{~m}^{2}$

- Tipologia: horizontal de baixo padrão, forma condominial aberta;

- Casas unifamiliares de $35 \mathrm{~m}^{2}$, em lotes de $160 \mathrm{~m}^{2}$

- 420 unidades habitacionais

- Áreas comuns: praça, playground, quadra, espaço comunitário, área para feira livre, equipamento escolar e religioso/cultural

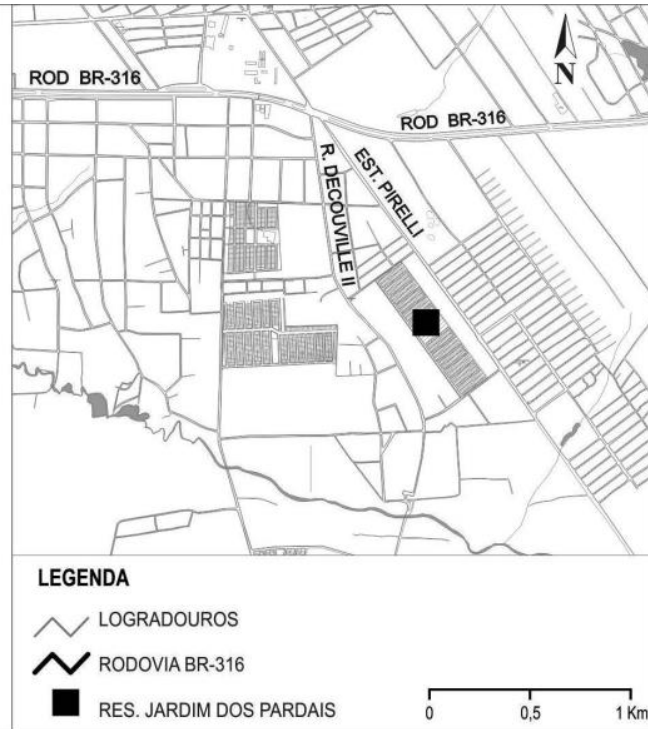

Fonte: adaptado de Pará (2009).

Figura 4 - Diagrama do sistema viário e localização das áreas residenciais, equipamentos de lazer infantil e comunitários do Residencial Jardim dos Pardais

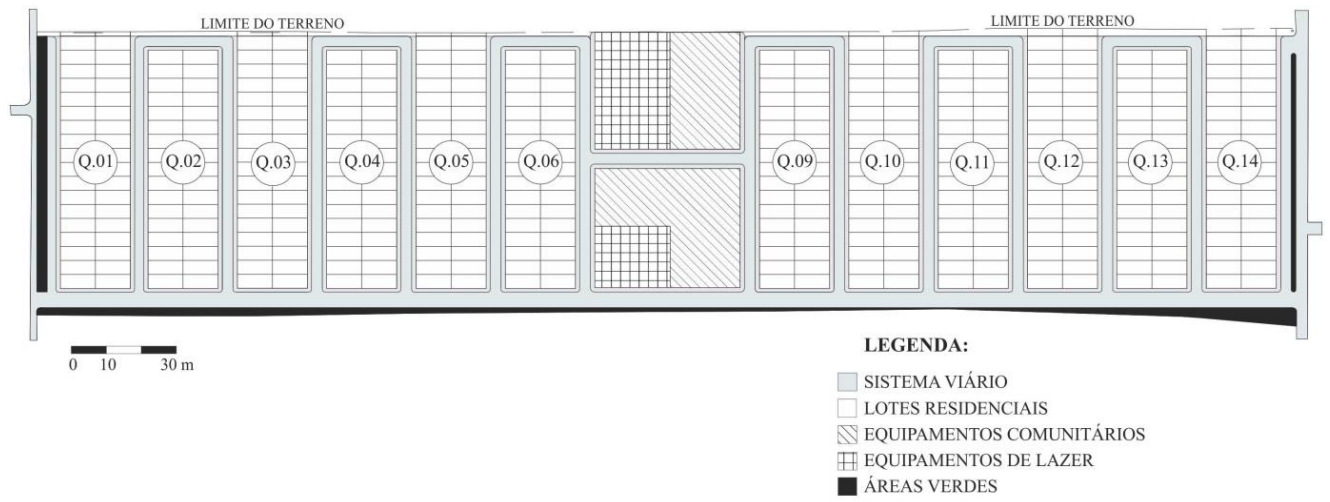

Fonte: adaptado de Pará (2009).

Figura 5 - Observação de vestígios físicos - Jardim dos Pardais

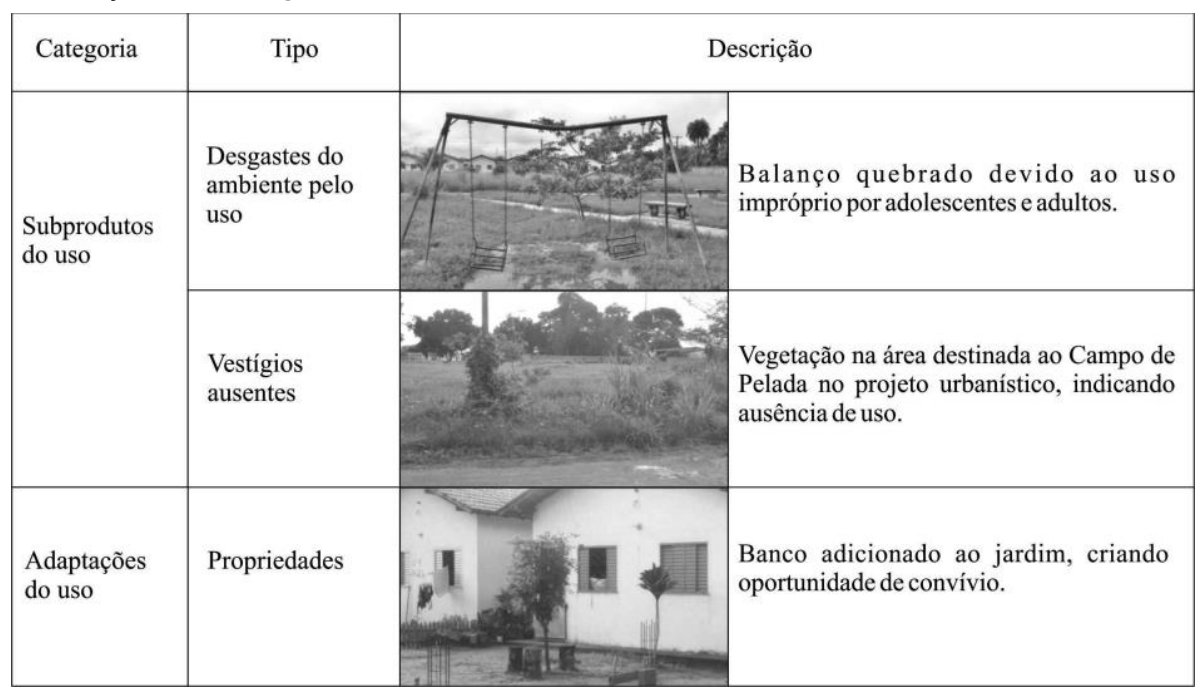


Figura 6 - Observação de vestígios físicos - Jardim Campo Grande

\begin{tabular}{|c|c|c|c|}
\hline Categoria & Tipo & \multicolumn{2}{|c|}{ Descrição } \\
\hline $\begin{array}{l}\text { Subprodutos } \\
\text { do uso }\end{array}$ & $\begin{array}{l}\text { Desgastes do } \\
\text { ambiente pelo } \\
\text { uso }\end{array}$ & 12 & $\begin{array}{l}\text { Gramado danificado ao lado da quadra de } \\
\text { areia, junto à calçada, devido ao uso pelos } \\
\text { que se reúnem para assistir ou participar } \\
\text { dos jogos. }\end{array}$ \\
\hline \multirow{2}{*}{$\begin{array}{l}\text { Adaptações } \\
\text { do uso }\end{array}$} & Propriedades & & $\begin{array}{l}\text { Casinha de brinquedo na frente do bloco } \\
\text { transformando área de estacionamento em } \\
\text { área de brincar. }\end{array}$ \\
\hline & Separações & 매 & $\begin{array}{l}\text { Vegetação separa visualmente acesso ao } \\
\text { bloco, ampliando a privacidade e gerando } \\
\text { possibilidade de aproveitamento do } \\
\text { espaço para lazer. }\end{array}$ \\
\hline
\end{tabular}

Figura 7 - Proporção de lotes, equipamentos, áreas verdes e sistema viário no Residencial Jardim dos Pardais

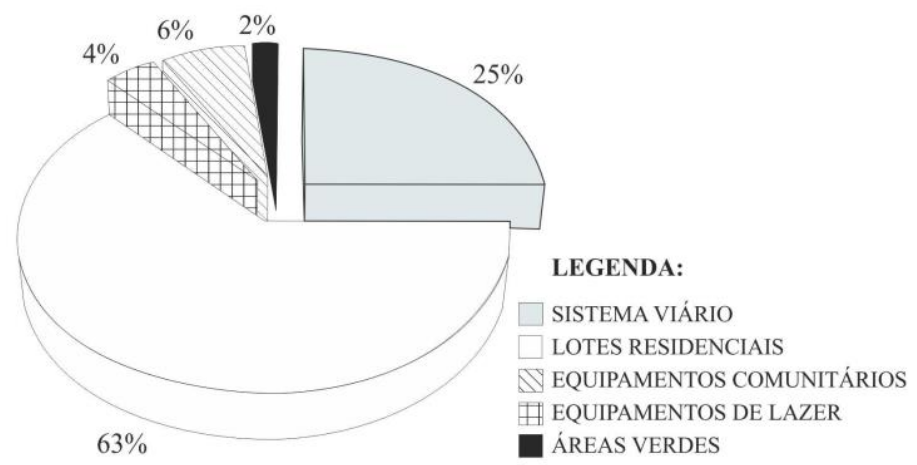

Fonte: adaptado de Pará (2009).

A mesma análise no Jardim Campo Grande aponta que as áreas residuais e de acesso aos blocos ocupam $28 \%$ da área do conjunto, seguido de $25 \%$ destinada aos blocos residenciais. Destaca-se que o percentual de ocupação para uso de estacionamento é de $22 \%$, enquanto as áreas de lazer e verde somam apenas $6 \%$ da área total, conforme se pode observar na Figura 8.

O projeto urbanístico do Residencial Jardim dos Pardais prevê como espaço de lazer infantil uma praça, onde estão situados playground, caixa de areia e área para recreação livre com vegetação, além de um campo de pelada, enquanto, para o Jardim Campo Grande, foram projetados um playground e uma quadra de areia para esse fim.

Se fosse aplicada aos dois residenciais a norma DIN 18034 (NEUFERT, 2013), seria preciso que destinassem $2.100 \mathrm{~m}^{2}$ a esse equipamento, uma vez que ambos possuem 420 unidades habitacionais. De acordo com a análise dos projetos urbanísticos dos conjuntos, há uma área destinada a playground no
Jardim dos Pardais de $1.316 \mathrm{~m}^{2}$, área 1,6 vez menor que a desejável de acordo com a norma alemã, enquanto o playground do Jardim Campo Grande tem apenas $228,30 \mathrm{~m}^{2}$, área 9,20 vezes menor que a indicada pela norma DIN 18034

Verifica-se, portanto, que os projetos arquitetônicos de ambos os conjuntos preveem espaço para lazer e recreação infantil, em obediência à Portaria n. 168/2013 do Ministério das Cidades (BRASIL, 2013), e apresentam semelhanças e diferenças em vários aspectos. Também foi efetuada a análise dessas áreas segundo o Roteiro de Observação dos Espaços de Lazer (Figura 8), de acordo com os quatro aspectos sugeridos: localização, equipamentos, configuração e ambientais.

Quanto ao aspecto "Localização", a praça e o campo de jogos do Jardim dos Pardais ficam localizados no centro do conjunto, porém o único acesso para as áreas de lazer se dá pela Rua WE-01, pela qual trafegam veículos em alta velocidade, e apenas os moradores das Alamedas 7 e 8 podem 
acessar diretamente essas áreas, pela Rua WE-02 (Figura 9).

Até o momento da pesquisa apenas o Centro Comunitário havia sido implantado, uma creche estava em construção e as áreas originalmente destinadas ao campo de pelada, feira livre/comércio e equipamento escolar apresentavam-se tomadas por vegetação rasteira. As casas das Alamedas 7 e 8 são voltadas para a Praça, o que indica a presença de aberturas que possibilitam a vigilância natural de que falava Jacobs (2003), porém, caso os equipamentos projetados estivessem em funcionamento, haveria grande circulação de pessoas no local, aumentando essa possibilidade.

Quanto à distância entre as casas e a praça, verificou-se aumento de $45 \mathrm{~m}$ em média a cada alameda, chegando a cerca de $370 \mathrm{~m}$ entre a
Alameda 14 e a Praça. Diante do modelo proposto por Dieckert e Monteiro (1983), a distância verificada no Residencial Jardim dos Pardais só seria adequada até as Alamedas 4 e 10 (Figura 10).

Quanto ao aspecto "Equipamentos", o projeto do Jardim dos Pardais inclui uma praça, projetada com bancos, caixa de areia, vegetação e playground equipado com três brinquedos, escorrega, gangorra e balanço, em uma área de $1.316,25 \mathrm{~m}^{2}$. No entanto, durante a observação em campo verificou-se que o playground do Residencial Jardim dos Pardais encontra-se em péssimo estado, com os brinquedos danificados e enferrujados, e que a área destinada à caixa de areia foi apropriada como campo de pelada e é utilizada por adolescentes e adultos. Também não há elementos móveis que permitam a interação das crianças.

Figura 8 - Proporção de lotes, equipamentos, áreas verdes, áreas de acesso/residuais, estacionamento e sistema viário no Residencial Jardim Campo Grande

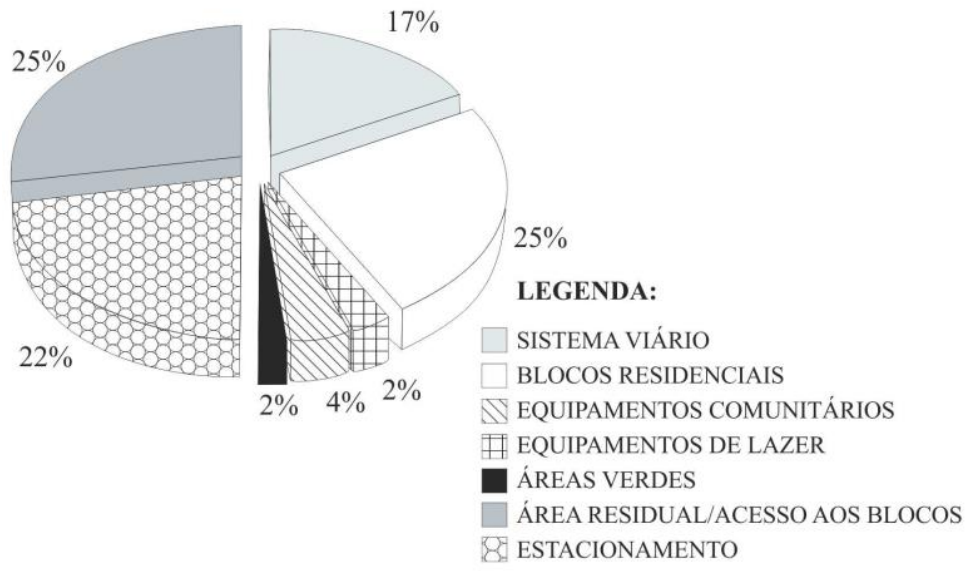

Fonte: adaptado de Construtora Acrópole (2014).

Figura 9 - Detalhe da localização das áreas de lazer do Residencial Jardim dos Pardais

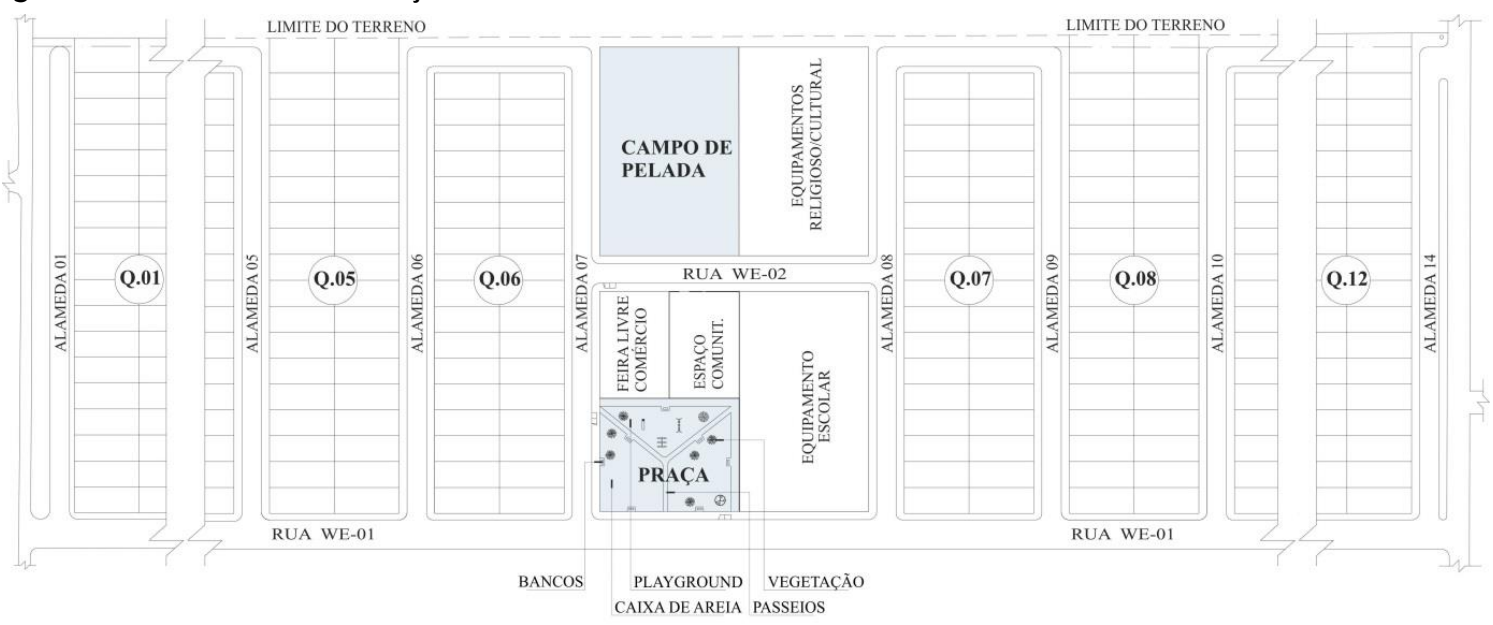

Fonte: adaptado de Pará (2009). 
Figura 10 - Distância aproximada entre a praça e as alamedas no Residencial Jardim dos Pardais (metros)

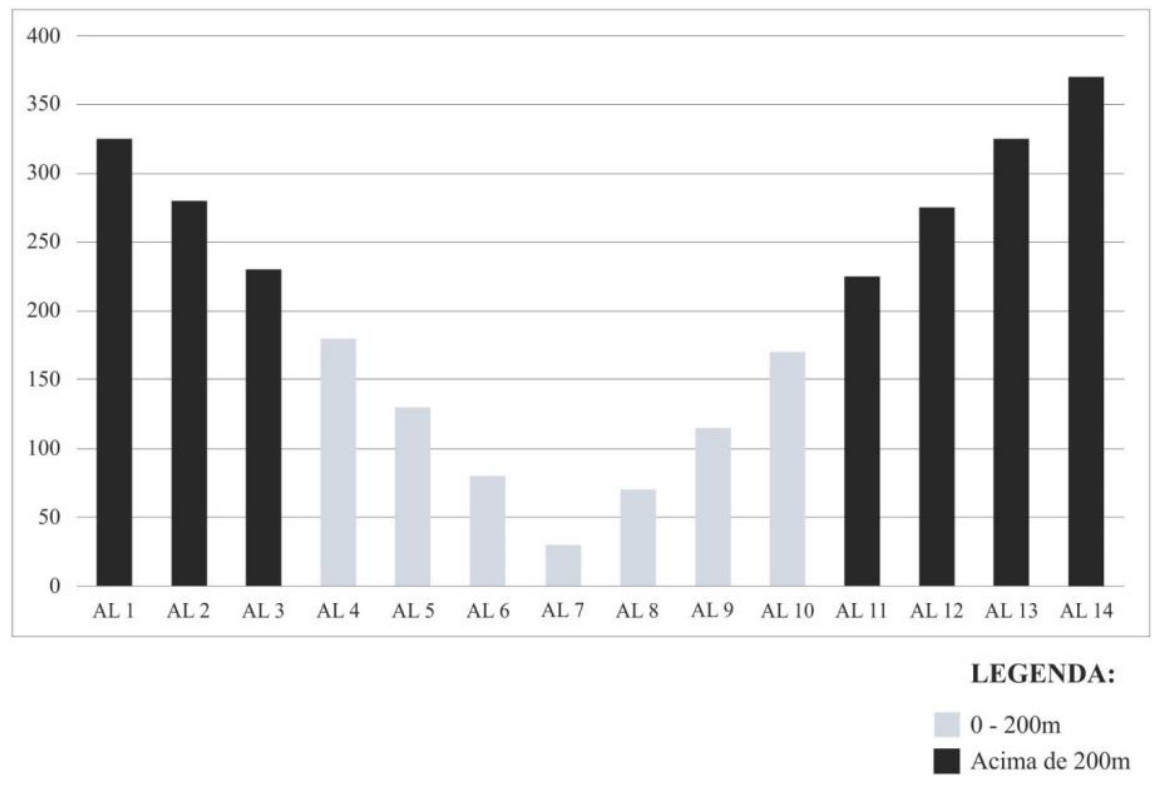

Fonte: adaptado de Pará (2009).

Figura 11 - Praça do Residencial Jardim dos Pardais
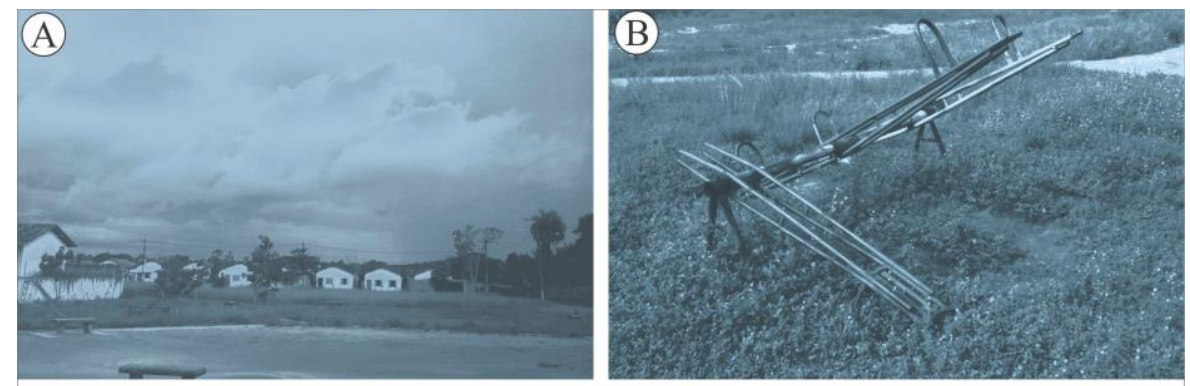

(A) Visão geral da praça

B) Gangorra quebrada e enferrujada

No que diz respeito ao aspecto "Configuração", foi reservada uma área de $2.770,46 \mathrm{~m}^{2}$ para campo de pelada, em frente à Praça, porém essa área se encontra em total desuso, como já foi citado, e o mesmo se dá com o espaço que serviria à recreação livre. É um espaço de baixa complexidade visual, onde não se encontram materiais e texturas variadas que estimulem os sentidos (Figura 11).

Quanto aos “Aspectos Ambientais”, a vegetação é escassa, com poucas árvores, ainda em crescimento, que não oferecem sombra, predominando a vegetação rasteira, que aos poucos invade também os passeios da Praça, o que dificulta a circulação e fornece ambiente adequado para a proliferação de roedores. Não há iluminação artificial específica para a área de lazer, apenas poucos postes de iluminação pública nas ruas do entorno.
As áreas de lazer no projeto do Residencial Jardim Campo Grande analisadas sob o aspecto "Localização" também estão situadas na porção central do conjunto, ficando a quadra de areia ao lado do Bloco 6 e o playground a $70 \mathrm{~m}$ de distância, em área residual ao redor do espaço multiúso, constatando-se aqui uma alteração realizada durante a obra, pois, de acordo com o projeto original, o reservatório elevado ficaria no local onde hoje se encontra o espaço multiúso (Figura 12).

Como se pode observar, a área projetada para o playground fica em uma das extremidades do conjunto, cercada por um muro lateral e outro nos fundos, contando apenas com as aberturas das janelas do Bloco 18 ao lado como possibilidade de exercer vigilância natural, pois o Bloco 17 tem sua visão prejudicada pelo ângulo em que está posicionado. A quadra de areia está situada em uma 
posição mais privilegiada, podendo ser observada a partir dos Blocos 6, 7 e 11, além de estar em um ponto de passagem para as Ruas 2, 3 e 4 .

$\mathrm{O}$ acesso a esses equipamentos é fácil, apesar das calçadas estreitas e impedidas em alguns pontos por carros estacionados e postes que induzem o uso das vias pelos pedestres, uma vez que a circulação de veículos no local é apenas dos moradores e que raramente os veículos trafegam em velocidade inadequada. A distância máxima entre os blocos e a quadra de areia, único equipamento de lazer ainda existente, é de $150 \mathrm{~m}$, não ultrapassando a distância recomendada por Dieckert e Monteiro (1983), situação mais favorável que a verificada no Jardim dos Pardais (Figura 13).

Figura 12 - Detalhe da localização das áreas de lazer do Residencial Jardim Campo Grande

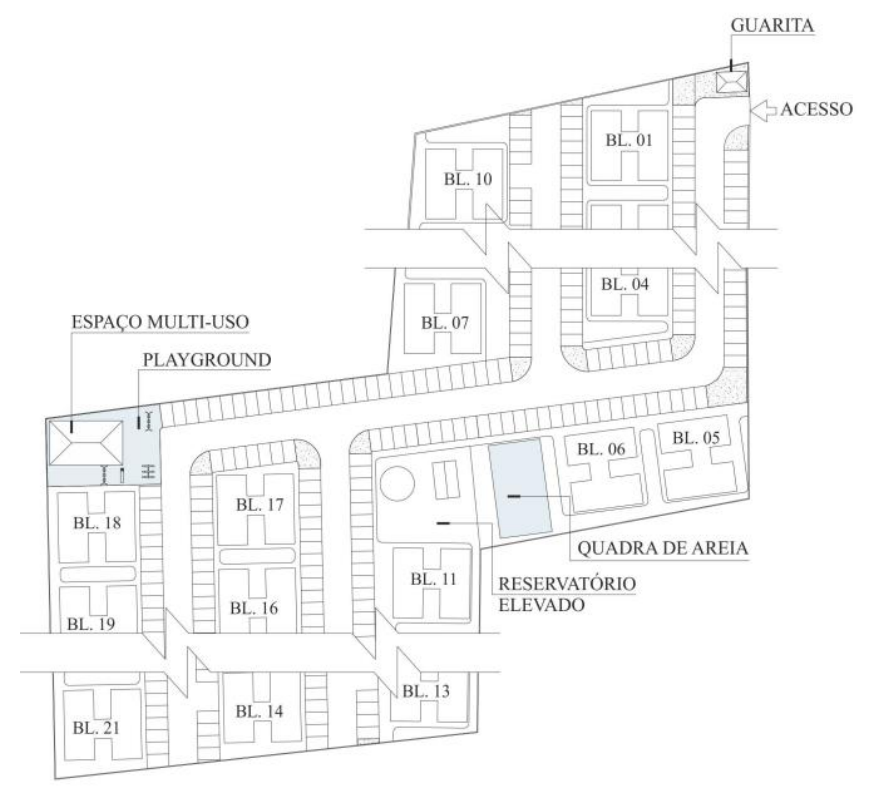

Fonte: adaptado de Construtora Acrópole (2014).

Figura 13 - Distância aproximada entre os blocos e a quadra de areia no Jardim Campo Grande (em metros)

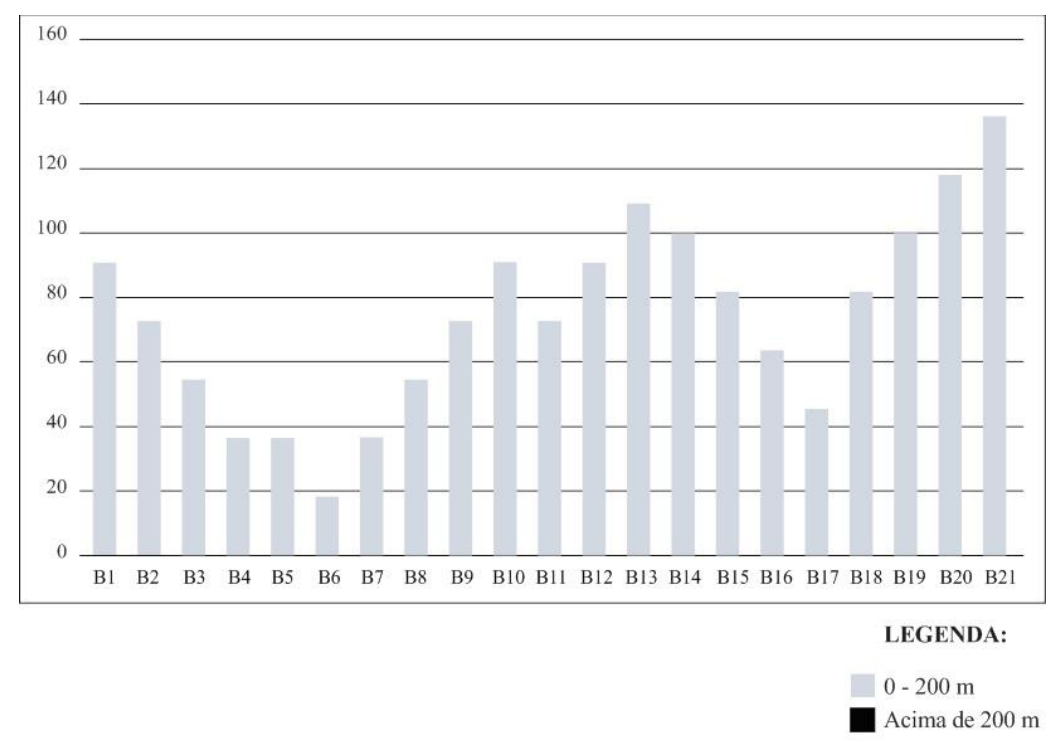

Fonte: adaptado de Construtora Acrópole (2014).

Quanto ao aspecto "Equipamentos", o playground projetado para o Jardim Campo Grande tem área de
205,30 $\mathrm{m}^{2}$ e conta com dois brinquedos a mais que o Jardim dos Pardais (escorrega, gangorra, dois 
balanços e carrossel), porém é cerca de 11 vezes menor do que a praça deste. Não há caixa de areia, bancos ou elementos interativos que despertem a curiosidade. $\mathrm{Na}$ primeira visita realizada ao conjunto pôde-se verificar que os brinquedos do playground estavam danificados e que um deles já havia sido retirado. Na segunda visita o playground já estava completamente desativado e os brinquedos depositados na área cercada do reservatório elevado, aguardando que o condomínio tivesse recursos para recuperá-los, segundo informações obtidas no local (Figura 14).

No que se refere ao aspecto "Configuração", a área projetada para o lazer do Residencial Jardim Campo Grande conta com uma quadra de areia de 202,50 $\mathrm{m}^{2}$ de área, porém, da mesma forma que no Jardim dos Pardais, ela não oferece materiais ou texturas variadas, sequer espaço para correr. Também apresenta pouca complexidade visual. Quanto aos "Aspectos Ambientais", a vegetação presente se limita à grama ao lado da quadra de areia, e a iluminação artificial específica é inexistente, como no Jardim dos Pardais (Figura 15).

De acordo com essa análise constata-se que, apesar das diferenças verificadas entre os espaços de lazer dos Residenciais Jardim Campo Grande e Jardim dos Pardais, os dois projetos apresentam deficiências e não atendem plenamente a nenhum dos aspectos considerados por esta pesquisa.

\section{Figura 14 - Playground do Residencial Jardim Campo Grande}
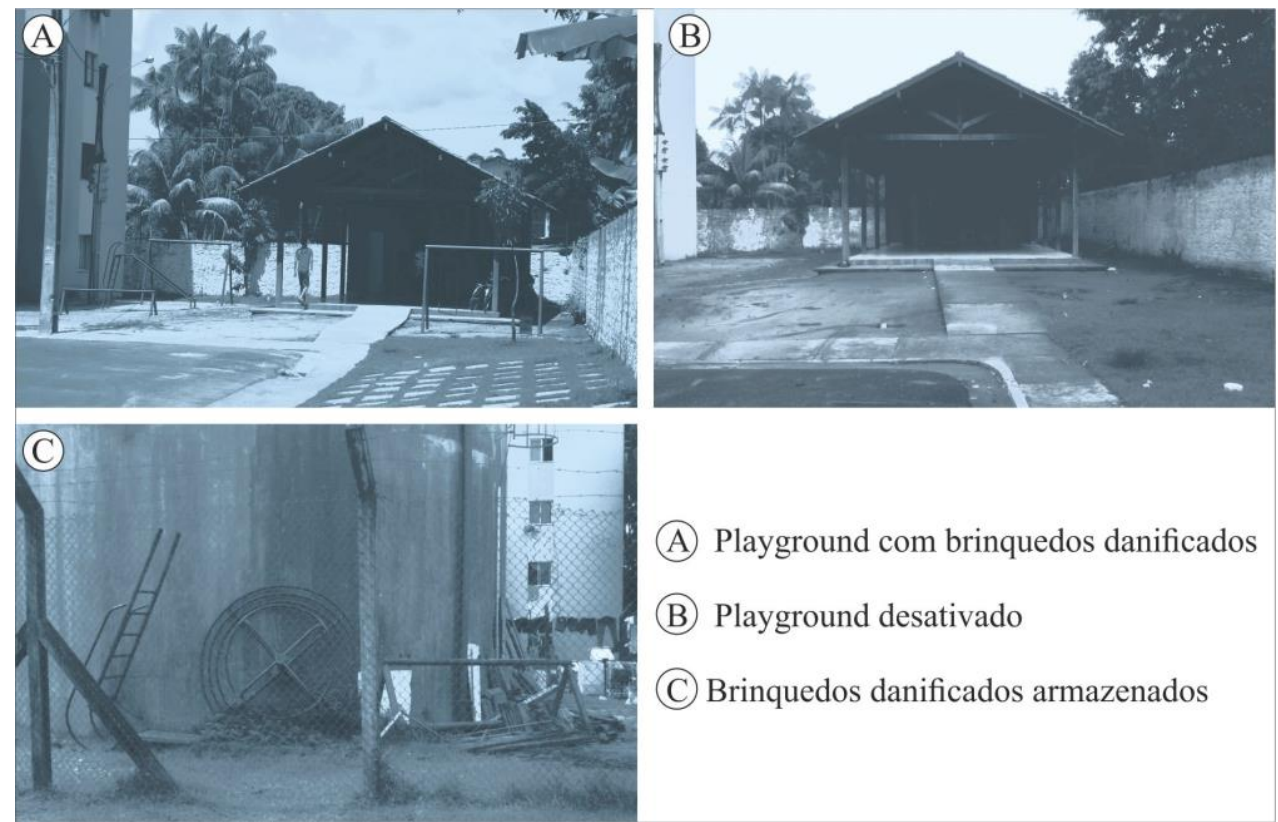

(A) Playground com brinquedos danificados

(B) Playground desativado

(C) Brinquedos danificados armazenados

Figura 15 - Quadra de areia no Residencial Jardim Campo Grande

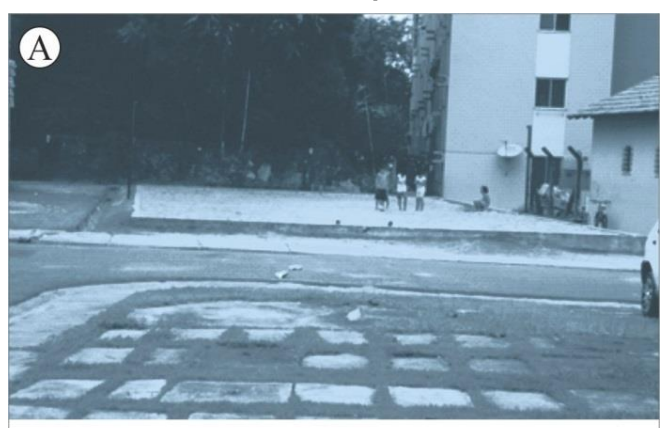

A) Quadra de areia 


\section{Observação comportamental nos Residenciais Jardim Campo Grande e Jardim dos Pardais}

Atendendo ao objetivo desta pesquisa, foi realizada observação comportamental do grupo de crianças moradoras nos Residenciais Jardim Campo Grande e Jardim dos Pardais, a fim de observar como elas têm-se relacionado com os espaços de lazer ou que espaços têm sido utilizados, ante o contraste casaapartamento, condomínio aberto-fechado, uma vez que, apesar do contexto socioeconômico semelhante, o contexto espacial é diverso.

As visitas aos residenciais com o propósito de observar as crianças foram realizadas em fins de semana, quando elas estariam liberadas de suas tarefas escolares e disponíveis para brincar, e no período da manhã, uma vez que, devido ao clima da região, as chuvas são frequentes durante a tarde. No entanto, nas primeiras observações realizadas no Jardim dos Pardais não se encontraram crianças brincando no espaço de lazer ou nas áreas livres do conjunto. Segundo informações obtidas no local, os próprios pais impedem que as crianças utilizem os espaços livres e de lazer pelos seguintes motivos:

(d) temem a violência, devido aos assaltos habituais na área;

(e) consideram inadequado o espaço da praça, frequentada por adolescentes e adultos, a maioria não residentes, que costumam jogar bola no que deveria ser a caixa de areia das crianças e que depredaram os brinquedos; e

(f) pelo risco de atropelamento na WE-01, por onde trafegam veículos pesados em alta velocidade.

Figura 16 - Mapa comportamental do Residencial Jardim dos Pardais

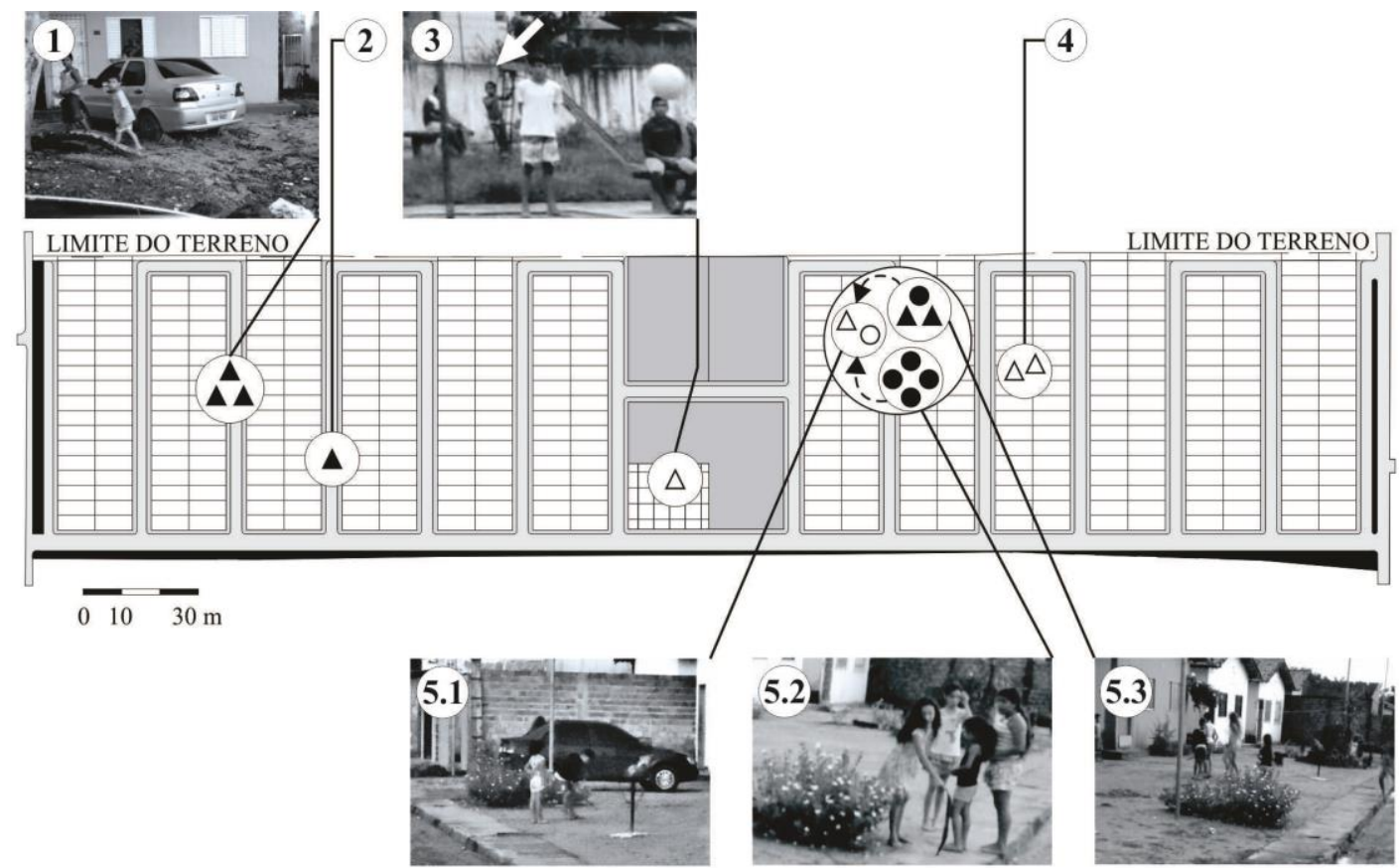

\begin{tabular}{|c|c|c|c|}
\hline $\begin{array}{l}\text { LEGENDA: } \\
\text { MENINA PARADA } \\
\triangle \text { MENINO PARADO } \\
- \text { MENINA EM MOVIMENTO } \\
\text { A MENINO EM MOVIMENTO } \\
\boxplus \text { PRAÇA } \\
--- \text { SEQUÊNCIA } \\
\text { COMPORTAMENTAL }\end{array}$ & 2 & $\begin{array}{l}\text { PASSEIO NA PORTA } \\
\text { Meninos passeando na frente de casa. } \\
\text { PASSEIO DE BICICLETA } \\
\text { Menino andando de bicicleta na } \\
\text { Alameda. } \\
\text { BRINCANDO NA PRAÇA } \\
\text { Ao fundo, menino brinca no } \\
\text { escorregador quebrado sob a } \\
\text { vigilância de um adulto, enquanto } \\
\text { adolescentes jogam vôlei na caixa de } \\
\text { areia apropriada como quadra. } \\
\text { ANIMAL DE ESTIMAÇÃO } \\
\text { Meninos brincando com gato na } \\
\text { frente de casa. }\end{array}$ & $\begin{array}{l}5 \text { BRINCADEIRAEM GRUPO } \\
\text { Observação de sequência } \\
\text { comportamental: } \\
5.1 \text { menino e } 1 \text { menina iniciam } \\
\text { brincadeira em frente de casa, sob a } \\
\text { vigilância da mãe; } \\
5.2 \text { um grupo de } 4 \text { meninas vindas de } \\
\text { outra casa reúne-se ao grupo } \\
\text { inicial; } \\
5.3 \text { rapidamente um terceiro grupo de } 2 \\
\text { meninos e } 1 \text { menina vindos de uma } \\
\text { terceira casa junta-se a estes, } \\
\text { formando um grupo de } 9 \text { crianças. }\end{array}$ \\
\hline
\end{tabular}


Como consequência do que foi descrito acima, as crianças só brincam nos pátios fechados (nas casas ampliadas) ou nas alamedas em frente às casas, sob a vigilância de adultos, em geral aos domingos ou no final da tarde, quando a mãe ou o pai retornam do trabalho e podem estar atentos, acrescentando ainda que normalmente a brincadeira acontece no final das alamedas, distante da WE-01. Além disso, o lazer eletrônico é estimulado pelos pais a fim de entreter as crianças nos momentos em que não podem vigiá-las. De posse dessas informações foram feitos os ajustes necessários para que a pesquisa pudesse ser efetivada. As observações realizadas no Jardim dos Pardais foram registradas no mapa comportamental demonstrado na Figura 16.

Durante as observações realizadas no Residencial Jardim Campo Grande percebeu-se que as crianças se deslocam e brincam sozinhas ou em grupos, sem a presença de adultos. Apesar do espaço reduzido e da inexistência de brinquedos, é marcante a presença de crianças especialmente nas vias internas no Residencial, que são pavimentadas e de tráfego restrito, propiciando que elas possam andar de bicicleta. A observação comportamental realizada no Residencial Jardim Campo Grande foi registrada no mapa comportamental apresentado na Figura 17.

De acordo com informações prestadas pela representante sindical, o uso indevido por adultos inutilizou os brinquedos do playground, que permaneciam danificados devido à falta de recursos do condomínio; pelo mesmo motivo a areia da quadra não teria sido trocada, o que causa micose nas crianças, que não deixam de usá-la. Ela acrescentou que os moradores dos apartamentos térreos reclamam do ruído das crianças que gostam de brincar em pequenos espaços junto aos blocos e que transformam o espaço multiúso em local de brincadeira, assegurando que os pais se sentem seguros de deixar seus filhos brincarem no interior do condomínio.

Assim, a observação comportamental revelou que as crianças que moram no Residencial Jardim Campo Grande têm maior liberdade para brincar nos espaços internos do conjunto, devido à sensação de segurança proporcionada pela tipologia de condomínio fechado, e acredita-se que a tipologia vertical é um fator que induz as crianças a usarem o espaço comum para brincar. Por outro lado, observou-se que as crianças residentes no Jardim dos Pardais têm sido cerceadas em seu direito ao lazer, ficando restritas em termos de espaço e tempo para brincar livremente, devido à sensação de insegurança, relacionada à tipologia de condomínio aberto. Considera-se também que a tipologia horizontal é um dos fatores que podem levar ao isolamento das crianças, limitando a brincadeira aos espaços de pátios, jardins e quintais cercados. É um paradoxo que as crianças que dispõem de mais espaço são as que menos usufruem desse espaço e que a alternativa adotada, o lazer eletrônico, não favorece seu desenvolvimento.

\section{Conclusão}

Os projetos dos Residenciais Jardim Campo Grande e Jardim dos Pardais previram espaços destinados ao lazer infantil, de acordo com a Portaria n. 168/2013 do Ministério das Cidades (BRASIL, 2013), representados por playground e quadra de areia. Entretanto, nenhum dos dois projetos atendeu totalmente aos aspectos e elementos considerados pela pesquisa, ainda que o projeto do Jardim dos Pardais possua mais elementos que o do Jardim Campo Grande, como também a área destinada ao lazer infantil é maior. Quanto à situação atual das instalações de lazer, ela é precária nos dois conjuntos devido à má qualidade dos brinquedos, ao uso indevido dos espaços por adultos e à incapacidade dos condomínios de fazer a manutenção adequada.

Quanto à análise da localização dos espaços para o lazer infantil para averiguar se é adequada, permitindo a supervisão dos adultos, verificou-se que no caso do Jardim dos Pardais, apesar de ocupar a área central do conjunto, o espaço de lazer tem seu acesso dificultado pelas condições das calçadas, pelo fato de que a única rua que conecta todas as alamedas à área de lazer recebe tráfego de veículos em velocidade inadequada e que a distância média entre a área de lazer e as alamedas é de 200 m, limite máximo segundo o critério estabelecido por Dieckert e Monteiro (1993) e adotado por esta pesquisa, podendo chegar a cerca de $370 \mathrm{~m}$ no ponto mais distante. Entretanto, permite a supervisão de adultos, seja pelos bancos instalados na praça, seja pelas fachadas das casas das Alamedas 7 e 8, e pelo fato de dois estabelecimentos comerciais estarem voltados para essa área. 
Figura 17 - Mapa comportamental do Residencial Jardim Campo Grande

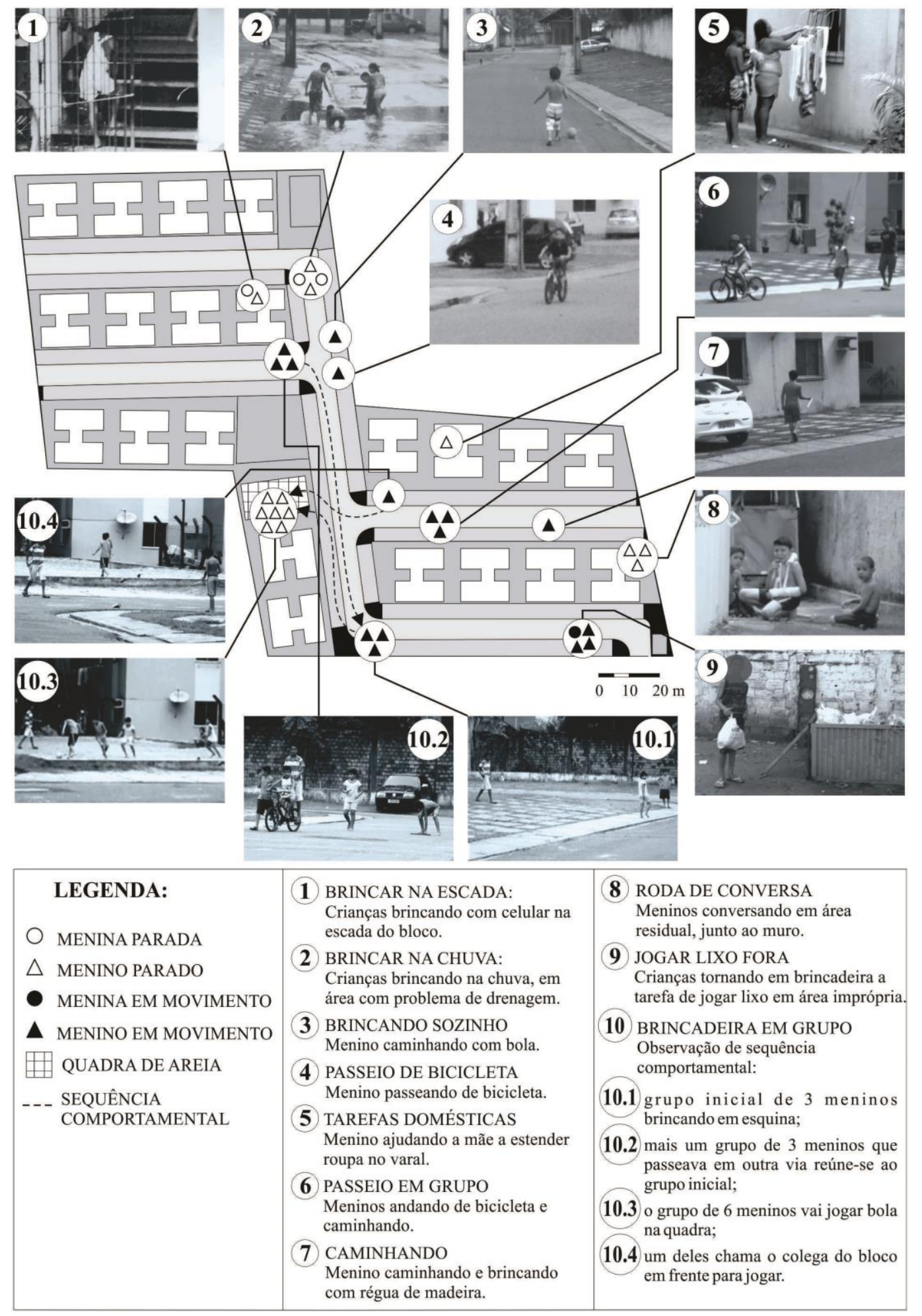

No caso do Jardim Campo Grande, o projeto previa que o playground distaria cerca de $70 \mathrm{~m}$ da quadra de areia e, apesar de ocupar a região central do conjunto, sua localização seria desfavorecida por situar-se em uma área limítrofe do residencial, com reduzida possibilidade de vigilância natural, porém esse playground encontra-se totalmente desativado atualmente. Quanto à quadra de areia deste residencial, sua localização é privilegiada por ser de fácil acesso, por permitir a vigilância natural por adultos e pelo fato de que a distância média entre os blocos de apartamentos e a quadra de areia é de 
cerca de $80 \mathrm{~m}$, e o bloco mais distante está a $150 \mathrm{~m}$ aproximadamente, o que ainda é adequado pelo critério adotado nesta pesquisa.

Observou-se que as crianças não têm utilizado os espaços de lazer nesses conjuntos, ou utilizam parcialmente, uma vez que estes não apresentam nem $50 \%$ dos elementos que atenderiam à necessidade de lazer e desenvolvimento infantil, não satisfazendo, portanto, a nenhum dos aspectos de forma plena. Além disso, observou-se que a quantidade de área destinada ao lazer ou ao espaço comum não interfere no uso, enquanto outros fatores podem limitar ou estimular o uso dessas áreas pelas crianças. Fatores como a sensação de segurança ou de insegurança, aliados à distância maior ou menor e às condições de acessibilidade, podem levar ao isolamento ou à socialização, assim como a tipologia habitacional pode induzir a um modo de vida mais privado ou coletivo.

Segundo os resultados desta pesquisa, a ausência ou inadequação de espaços de lazer infantil nos empreendimentos do PMCMV faixa 1 têm levado as crianças a se apropriarem dos espaços de uso comum como alternativa ao lazer, o que representa a falta de adequação entre o projeto e a apropriação dos espaços públicos. Ante o reconhecimento da importância do lazer infantil para o desenvolvimento da criança, do lazer como um direito em si, que também está vinculado ao direito à moradia digna, entende-se que as diretrizes para a elaboração dos projetos de conjuntos habitacionais de interesse social do PMCMV deveriam também estabelecer critérios qualitativos para os projetos de espaços de lazer infantil que levem em conta as necessidades específicas dos usuários crianças.

\section{Referências}

ALEXANDER, C. Uma Linguagem de Padrões. Porto Alegre: Bookman, 2013.

ANANINDEUA. Secretaria Municipal de Habitação. [Informações Obtidas em Entrevista Com Técnicos da Secretaria]. 2014.

ASSOCIAÇÃO BRASILEIRA DE NORMAS TÉCNICAS. NBR 14350: segurança de brinquedos de playgraound: parte 1: requisitos e métodos de ensaio. Rio de Janeiro, 1999.

AZEVEDO, S. Vinte e Dois Anos de Política de Habitação Popular (1964-86): criação, trajetória e extinção do BNH. Revista de Administração Pública, v. 22, n. 4, p. 107-119, 1988.
AZEVEDO, S. Desafios da Habitação Popular no Brasil: políticas recentes e tendências. In: CARDOSO, A. L. (Org.). Habitação Social nas Metrópoles Brasileiras. Porto Alegre: Finep, 2007. Coleção Habitare.

BENETTI, P. Habitação Social e Cidade. Rio de Janeiro: Rio Book's, 2012.

DEUTSCHE INSTITUT FÜR NORMUNG. DIN

7926: Kinderspielgeräte: Begriffe: Anforderungen: Prüfung. Berlin, 1983.

\section{DEUTSCHE INSTITUT FÜR NORMUNG. DIN}

18034: Spielplätze und Freiräume zum Spielen: Anforderungen für Planung, Bau und Betrieb. Berlin, 2012.

BONDUKI, N. Política Habitacional e Inclusão Social no Brasil: revisão histórica e novas perspectivas no governo Lula. Revista Eletrônica de Arquitetura e Urbanismo, v. 1, 2008.

BONDUKI, N. Origens da Habitação Social no Brasil: arquitetura moderna, lei do inquilinato e difusão da casa própria. São Paulo: Estação Liberdade, 2011.

\section{BORGES, M. M. F. C. Diretrizes Para Projetos} de Parques Infantis Públicos. Florianópolis, 2008. Dissertação (Mestrado em Arquitetura e Urbanismo) - Universidade Federal de Santa Catarina, Florianópolis, 2008.

BOTAS, N. C. A. Concreto, Muxarabis e Cumeeiras Para os Industriários: a arquitetura e o urbanismo de Carlos Frederico Ferreira na produção do IAPI. In: ENCONTRO NACIONAL DA ASSOCIAÇÃO NACIONAL DE PESQUISA E PÓS-GRADUAÇÃO EM ARQUITETURA E URBANISMO, 1., Rio de Janeiro, 2010. Anais... Rio de Janeiro, 2010.

BRASIL. Ministério das Cidades. Portaria 168, de 12 de abril de 2013, que dispõe sobre as diretrizes gerais para aquisição e alienação de imóveis com recursos advindos da integralização de cotas do Fundo de Arrendamento Residencial FAR, no âmbito do Programa Nacional de Habitação Urbana - PNHU, integrante do Programa Minha Casa, Minha Vida - PMCMV.

BRUNA, P. Os Primeiros Arquitetos Modernos: habitação social no Brasil 1930-1950. São Paulo: Edusp, 2010.

CAMARGO, L. O. L. O Que é o Lazer? São Paulo: Círculo do Livro, 1984. 
CARDOSO, A. Habitação de Interesse Social: política ou mercado? Reflexos sobre a construção do espaço metropolitano. In: ENCONTRO NACIONAL DA ASSOCIAÇÃO NACIONAL DE PÓS-GRADUAÇÃO E PESQUISA EM PLANEJAMENTO URBANO E REGIONAL, 14., Rio de Janeiro, 2011. Anais... Rio de Janeiro: ANPUR, 2011

CARDOSO, A.; ARAGÃO, T. A. Do Fim do BNH ao Programa Minha Casa Minha Vida: 25 anos da política habitacional no Brasil. In CARDOSO, A. (Org.). O Programa Minha Casa Minha Vida e Seus Efeitos Territoriais. Rio de Janeiro: Letra Capital, 2013.

CASTRIOTA, L. B.; ARAÚJO, G. M. Patrimônio, Valores e Historiografia: a preservação do conjunto habitacional do Instituto de Aposentadorias e Pensões dos Industriários - IAPI Arquitetura Revista, São Leopoldo, v. 5, n. 1, p. 38-54, jan. 2009.

CHOAY, F. O Urbanismo: utopias e realidades, uma antologia. São Paulo: Perspectiva, 2005.

CONSTRUTORA ACRÓPOLE. Planta de Urbanização do Residencial Jardim Campo Grande. Arquivo em CAD, não publicado. 2014.

DIECKERT, J.; MONTEIRO, F. D. Parque de Esporte e Lazer Para Todos. Santa Maria: MEC; Seed, 1983.

DINIZ, L. N. Conjunto Habitacional Presidente Getúlio Vargas: da proposta monumental a sobrevivência nos dias atuais. In: SEMINÁRIO DOCOMOMO, 7., Porto Alegre, 2007. Anais... Porto Alegre, 2007.

FERNANDES, E. O Estatuto da Cidade e a Ordem Júrídico-Urbanística. In: CARVALHO, C. S.; ROSSBACH, A. (Orgs.). O Estatuto da Cidade: comentado. São Paulo: Ministério das Cidades: Aliança das Cidades, 2010.

FERREIRA NETO, C. A. Motricidade e Jogo na Infância. Rio de Janeiro: Sprint, 1995.

INSTITUTO BRASILEIRO DE GEOGRAFIA E ESTATISTÍCA. Censo Demográfico 2010:

nupcialidade, fecundidade e migração: resultados da amostra. Rio de Janeiro, 2010.

JACOBS, J. Morte e Vida de Grandes Cidades. São Paulo: Martins Fontes, 2003.

LE CORBUSIER. (1957). A carta de Atenas. São Paulo: Hucitec; Edusp, 1993.

LIMA, J. J. F.; CARDOSO, A. C. D.; HOLANDA, A. C. G. Impasses e Desafios na Gestão da Região Metropolitana de Belém. Cadernos Metrópole, v. 14, p. 103-126, segundo semestre, 2005.
LIMA, M. S. A Cidade e a Criança. São Paulo: Nobel, 1989.

MARCELLINO, N. C. Estudos do Lazer: uma introdução. Campinas: Autores Associados, 2002.

MCCURDY, L.; WINTERBOTTOM, K.;

MEHTA, S. S. Using Nature and Outdoor Activity to Improve Children's Health. Current Problems in Pediatric and Adolescent Health Care, New York, v. 40, p. 102-117, 2010.

MELO, M. A. B. C. Política de Habitação e Populismo: o caso da Fundação da Casa Popular. Revista de Urbanismo e Arquitetura, v. 3, n. 1, p. 39-64, 1990.

MENDES, I. C. R. Programa Favela-Bairro: uma inovação estratégica? Estudo do Programa Favela-Bairro no contexto do Plano Estratégico da Cidade do Rio de Janeiro. São Paulo, 2006.

Dissertação (Mestrado em Arquitetura e Urbanismo) - Escola de Arquitetura e Urbanismo, Universidade de São Paulo, São Paulo, SP, 2006.

MINDLIN, H. E. Arquitetura Moderna no Brasil. Rio de Janeiro: Aeroplano; Iphan, 2000.

NEUFERT, E. Arte de Projetar em Arquitetura. São Paulo: Gustavo Gili, 2013.

OLIVEIRA, C. O Ambiente Urbano e a Formação da Criança. São Paulo: Aleph, 2004.

PANTOJA, L. C. M. P. Mercado de São Brás e Seu Entorno: tramas e sentidos de um lugar. Belém, 2014. Dissertação (Mestrado em Arquitetura e Urbanismo) - Programa de PósGraduação em Arquitetura e Urbanismo, Universidade Federal do Pará, Belém, 2014.

PARÁ. Companhia Habitacional do Pará. Planta de Urbanização do Residencial Jardim dos Pardais. Arquivo em CAD, não publicado. 2009.

PIAGET, J. Seis Estudos de Psicologia. Rio de Janeiro: Forense Universitária, 2013.

PINA, L. W. O Parque Lúdico: a construção de um novo conceito do brincar. In: MIRANDA, D. S. (Org.). O Parque e a Arquitetura: uma proposta lúdica. Campinas: Papirus, 1996.

REIS, T.; LAY, M. C. D. O Projeto da Habitação de Interesse Social e a Sustentabilidade Social. Ambiente Construído, Porto Alegre, v. 10, n. 3, p. 99-119, jul./set. 2010.

SANTINI, R. C. G. Dimensões do Lazer e da Recreação: questões espaciais, sociais e psicológicas. São Paulo: Angelotti, 1993. 
SAULE JÚNIOR, N.; UZZO, K. A Trajetória da Reforma Urbana no Brasil. In: ENCONTRO ANUAL DA REDE BRASILEIRA DE CIDADES MÉDIAS, 3., Cachoeira, 2013. Anais... Cachoeira, 2013.

TRINDADE JÚNIOR, S.C. Produção do Espaço e Uso do Solo Urbano em Belém. Belém, 1993.

Dissertação (Mestrado em Planejamento do Desenvolvimento) - Universidade Federal do Pará, Belém, 1993.

UNIVERSIDADE FEDERAL DO PARÁ; CONSELHO NACIONAL DE

DESENVOLVIMENTO CIENTÍFICO E TECNOLÓGICO. Avaliação da Produção Imobiliária de Interesse Social no Âmbito do PMCMV no Estado do Pará: relatório final. Belém: UFPA; Labcam, 2015.
VELASCO, C. G. Brincar: o despertar psicomotor. Rio de Janeiro: Sprint, 1996.

YIN, R. K. Estudo de Caso: planejamento e métodos. Porto Alegre: Bookman, 2001.

ZEISEL, J. Inquiry by Design: tools for environment-behavior research. Cambridge: Press Syndicate of the University of Cambridge, 1993.

\section{Agradecimento}

A pesquisa que originou este artigo foi em parte financiada com recursos do $\mathrm{CNPq}$ através do Projeto Avaliação da Produção Imobiliária de Interesse Social no Âmbito do Programa Minha Casa, Minha Vida, no Estado do Pará (550725/2012-1 Chamada MCTI/CNPq/ MCIDADES N ${ }^{\circ} 11 / 2012$ ). 


\section{Errata}

No artigo "O espaço para crianças produzido pelo programa Minha Casa, Minha Vida: estudo de caso na região metropolitana de Belém, PA", com número de DOI: <http://dx.doi.org/10.1590/s167886212017000200148>, publicado no periódico Ambiente Construído, 17(2):97-117.

Na página 97:

Onde se lia (rodapé):

"O espaço para crianças produzido pelo programa Minha Casa, Minha Vida: estudo de caso na região metropolitana de Belém, PR"

Leia-se:

"O espaço para crianças produzido pelo programa Minha Casa, Minha Vida: estudo de caso na região metropolitana de Belém, PA"

\section{Na página 107:}

Onde se lia:

"Se fosse aplicada aos dois residenciais a norma DIN 18034, seria preciso que destinassem $2.100 \mathrm{~m}^{2}$ a esse equipamento, uma vez que ambos possuem 420 unidades habitacionais. De acordo com a análise dos projetos urbanísticos dos conjuntos, há uma área destinada a playground no Jardim dos Pardais de 1.316 $\mathrm{m}^{2}$, área 1,6 vez menor que a desejável de acordo com a norma alemã, enquanto o playground do Jardim Campo Grande tem apenas 228,30 m², área 9,20 vezes menor que a indicada pela norma DIN 18034 ."

Leia-se:

Se fosse aplicada aos dois residenciais a norma DIN 18034 (DEUTSCHE..., 2012), seria preciso que destinassem $2.100 \mathrm{~m}^{2}$ a esse equipamento, uma vez que ambos possuem 420 unidades habitacionais. De acordo com a análise dos projetos urbanísticos dos conjuntos, há uma área destinada a playground no Jardim dos Pardais de $1.316 \mathrm{~m}^{2}$, área 1,6 vez menor que a desejável de acordo com a norma alemã, enquanto o playground do Jardim Campo Grande tem apenas 228,30 $\mathrm{m}^{2}$, área 9,20 vezes menor que a indicada pela norma DIN 18034 (DEUTSCHE..., 2012).

Na página 116: acréscimo das referências:

DEUTSCHE INSTITUT FÜR NORMUNG. DIN 7926: Kinderspielgeräte: Begriffe: Anforderungen: Prüfung. Berlin, 1983.

DEUTSCHE INSTITUT FÜR NORMUNG. DIN 18034: Spielplätze und Freiräume zum Spielen: Anforderungen für Planung, Bau und Betrieb. Berlin, 2012.

Na página 117:

Onde se lia:

"Shirley Coelho Müller

Mestra em Arquitetura e Urbanismo | Universidade Federal do Pará | Rua Augusto Correa, 1, Guamá | Belém - PA - Brasil | CEP 66075-110 | Tel.: (91) 3224-1966 | E-mail: shirleymuller04@ gmail.com"

Leia-se:

"Shirley Coelho Müller

Mestra em Arquitetura e Urbanismo pelo Programa de Pós-Graduação em Arquiterura e Urbanismo | Universidade Federal do Pará | Avenida Gentil Bittencourt, 1185/1901, Nazaré | Belém - Pa - Brasil | CEP 66040-174 | Tel.: (91) 3224-1966 | E-mail: shirleymuller04@ gmail.com" 